Georgetown University Law Center

Scholarship @ GEORGETOWN LAW

2022

\title{
Rebuilding Platform Antitrust: Moving on from Ohio v. American Express
}

Steven C. Salop

Georgetown University Law Center, salop@law.georgetown.edu

Daniel Francis

Harvard Law School

Lauren Sillman

Clifford Chance LLP

Michaela Spero

Amadeus

This paper can be downloaded free of charge from:

https://scholarship.law.georgetown.edu/facpub/2414

https://ssrn.com/abstract=3959827

This open-access article is brought to you by the Georgetown Law Library. Posted with permission of the author. Follow this and additional works at: https://scholarship.law.georgetown.edu/facpub

Part of the Antitrust and Trade Regulation Commons 


\title{
REBUILDING PLATFORM ANTITRUST: MOVING ON FROM OHIO V. AMERICAN EXPRESS
}

\author{
Steven C. Salop, Daniel Francis, Lauren Sillman, \& Michaela Spero*
}

\begin{abstract}
Now that the immediate fallout from the Supreme Court's blockbuster Amex decision has cooled, this Article aims to give a first draft of its place in antitrust history and to offer a roadmap for the next stage of the evolution of platform antitrust analysis. We focus on several issues that have not been fully analyzed in the literature. First, we argue that, rather than mangling the law of market definition, the Court should have explicitly permitted multi-market balancing of effects across the separate markets in which the platform was active. Second, we propose standards to implement such balancing in cases involving multisided platforms in a principled manner, and we illustrate those standards by application to the facts of Amex itself. Third, we highlight three significant omissions in the Court's analysis that confounded its assessment of the case and threaten to mislead future courts. In particular, we show that the Court failed to take into account that: (1) all three major card networks had parallel anti-steering rules during the period of alleged anticompetitive conduct and harm, which increased the anticompetitive harms by (a) increasing the incentives for fee increases for each network, (b) reducing the incentives for fee decreases by each network, and (c) leading the Amex restraints to harm holders of other credit cards as well as consumers who pay with debit, cash and checks; (2) higher merchant fees caused by these parallel antisteering rules placed consumers into a prisoners' dilemma game, which led inevitably to increased use of credit cards above the efficient, competitive level, making the volume of card transactions a poor proxy for welfare effects; and; (3) American Express' cardholder rewards were not necessarily evidence of procompetitive consumer benefits, as some rewards may have represented rents from anticompetitive conduct. Finally, we suggest several options for the courts and Congress to remedy the problems caused by the Court's faulty approach and place platform antitrust back on track.
\end{abstract}

\section{INTRODUCTION}

On June 25, 2018, the U.S. Supreme Court issued what may be the worst antitrust decision in many decades: Ohio v. American Express Co. ("Amex"). ${ }^{1}$ In an opinion authored by Justice Thomas for a bare majorityand over an incredulous dissent— the Court dismissed an antitrust challenge

\footnotetext{
* Professor of Economics \& Law, Georgetown University Law Center (Salop); Assistant Professor of Law, NYU School of Law (Francis); Staff Attorney, Federal Trade Commission (Sillman) (written in her personal capacity and not as a representative of the FTC; the views expressed are her own and not necessarily those of the Commission or any individual Commissioner); Legal Counsel Regulatory Affairs, Amadeus (Spero). For immensely helpful and generous comments, we are grateful to Erik Hovenkamp, Herbert Hovenkamp, Al Klevorick, Douglas Melamed, John Newman, Sharis Pozen, John Robertson, and Irving Scher, as well as Tammy Feldman, Tina Miller, and three anonymous peer reviewers for the Antitrust Law Journal.

${ }^{1} 138$ S. Ct. 2274 (2018). Candidates for the previous record-holder could include, in no particular order, Appalachian Coals, Inc. v. United States, 288 U.S. 344 (1933); United States v. U.S. Steel Corp., 251 U.S. 417 (1920); United States v. Arnold, Schwinn \& Co., 388 U.S. 365 (1967); and United States v. Von's Grocery Co., 384 U.S. 270 (1966).
} 
to American Express's “antisteering” rules, despite ample evidence of harm furnished by a lengthy trial, as well as the teachings of economic theory. In doing so, the Court upended a series of legal fundamentals, inverted accepted practices in the interpretation of evidence, and plunged platform antitrust into confusion. ${ }^{2}$

The Court's tortured analysis has left courts, agencies, and businesses with a host of puzzles; triggered a flurry of scholarship and commentary, mostly very critical; ${ }^{3}$ and invited a flurry of ill-conceived litigation arguments. ${ }^{4}$ The practical inheritance of Amex is plain to see: the burdens faced by plaintiffs have been needlessly increased, and enforcement efforts have been obstructed. ${ }^{5}$ At least one high-profile merger challenge has already failed as a direct result of Amex's legacy of confusion, ${ }^{6}$ and the decision will continue to haunt and obscure the antitrust analysis of "Big Tech" platform practices for years to come.

Much has been written about Amex. Commentators have criticized the opinion in a variety of respects, including its treatment of market definition and its handling of effects evidence. ${ }^{7}$ Some commentators have also criticized the Court's introduction of a formal market-definition requirement for vertical cases, and its refusal to accept direct evidence of anticompetitive effects as proof of market power. ${ }^{8}$ Others have critically

\footnotetext{
2 Note that the Court used the terms "two-sided market" and "platform" interchangeably. To avoid confusion with the antitrust concept of a relevant product market, in this article, we use the term "platform" to refer to multisided business models and the term "market" when discussing antitrust market definition. See generally infra Section II.B.2.

${ }^{3}$ See, e.g., Michael Katz \& Jonathan Sallet, Multisided Platforms and Antitrust Enforcement, 127 YALE L.J. 2142, 2154 (2018); Dennis W. Carlton, The Anticompetitive Effects of Vertical Most-FavoredNation Restraints and the Error of Amex, 2019 Columbia Bus. L. ReV. 93 (2019); Herbert Hovenkamp, Platforms and the Rule of Reason: The American Express Case, 2019 ColumBIA Bus. L. Rev. 35 (2019); Erik Hovenkamp, Platform Antitrust, 44 J. Corp. L. 713 (2019); Michael L. Katz \& A. Douglas Melamed, Competition Law as Common Law: American Express and the Evolution of Antitrust, 168 U. PENN. L. Rev. 2061 (2020); Natasha Sarin, What's in Your Wallet (and What Should the Law Do About It?), U. Chi. L. Rev. 553 (2020). See also, e.g., Joshua D. Wright \& John M. Yun, Ohio v. American Express: Implications for Non-Transaction Multisided Platforms, Competition Pol'y Intl. Antitrust Chronicle (June 2019) (endorsing Amex).

${ }^{4}$ See, e.g., United States v. Sabre Corp., 452 F. Supp. 3d 97 (D. Del. 2020); Defendant's Supplemental Briefing on United States v. Am. Express, United States v. Charlotte-Mecklenburg Hosp. Auth., No. 3:16-cv-00311-RJC-DCK (W.D.N.C. Oct. 12, 2016).

${ }_{6}^{5}$ See US Airways, Inc. v. Sabre Holdings Corp, 938 F.3d 43 (2d Cir. 2019).

${ }^{6}$ The reasoning of the district court in United States $v$. Sabre Corp. was strongly influenced by the Amex decision, as discussed infra.

7 See, e.g., Erik Hovenkamp, Platform Antitrust, 44 J. Corp. L. 713 (2019); Michael L. Katz \& A. Douglas Melamed, Competition Law as Common Law: American Express and the Evolution of Antitrust, 168 U. PA. L. REV. 2061 (2020); John B. Kirkwood, Antitrust and Two-Sided Platforms: The Failure of American Express, 41 CARDOZO L. REV. 1805 (2020).

${ }^{8}$ See e.g., Herbert Hovenkamp, Platforms and the Rule of Reason: The American Express Case, 2019 Columbia Bus. L. Rev. 35 (2019).
} 
analyzed the Court's use of economic theory and evidence, including with respect to the impact of the antisteering rules on competition, ${ }^{9}$ as well as the Court's reliance on the fact of market growth as evidence that the restraints were procompetitive. ${ }^{10}$ And, while the balance of scholarly commentary has been negative, some have defended the Court's decision and reasoning, ${ }^{11}$ while others have favored the decision but not the reasoning. ${ }^{12}$

This Article looks to the future. Our aim is to provide a general framework for courts and agencies to use in confronting practices and transactions in future platform cases. We draw on litigation evidence and economic theory to explain why the approach and reasoning of the Amex decision was objectionable, and to offer a better method for future platform antitrust matters. In particular, we build on the idea that appears to have motivated the Court in Amex - that certain platform cases may compel a special approach grounded in the distinctive economics of multisided businessesand develop an alternative for courts and agencies to the flawed and incomplete analysis that permeates the opinion. We propose a set of principles to guide balancing in platform cases to replace the Court's misguided approach, and we demonstrate the utility of those principles by applying them to the Amex trial record, including some underappreciated aspects of that record. We also offer some practical suggestions for courts and legislators to help put Amex behind us and right the ship of platform antitrust.

We proceed in four Parts. Part I sets out the evidentiary record (including critical facts ignored or marginalized by the Court), as well as the holdings of the Amex courts upon that record. Part II crystallizes the Amex's Court's analytical errors - both legal and economic — and outlines a better approach to platform antitrust cases: one that accurately reflects economic realities in platform cases while preserving antitrust's legal fundamentals. Part III demonstrates the utility of our proposed approach by applying it to Amex itself. Finally, Part IV briefly outlines three routes back to a sensible platform antitrust framework: a clean course-correction by the Supreme Court; limiting decisions by lower courts that would take seriously the

\footnotetext{
${ }^{9}$ See e.g., Dennis W. Carlton \& Ralph A. Winter, Vertical MFN's and the Credit Card No-Surcharge Rule, 61 J.L. \& ECON. 215 (2018).

${ }^{10}$ See e.g., John Newman, The Output-Welfare Fallacy: A Modern Antitrust Paradox, 107 Iowa L. Rev. 563 (2022).

${ }^{11}$ See e.g., Joshua D. Wright \& John M. Yun, Ohio v. American Express: Implications for NonTransaction Multisided Platforms, Competition Pol'y Intl. Antitrust Chronicle (June 2019) (proposing the retention and extension of Amex).

${ }^{12}$ See e.g., Aaron M. Panner, Market Definitions and Anticompetitive Effects In Ohio v. American Express, 130 YALE L.J. ForUM 608 (2021).
} 
many limiting conditions that were expressed and implied in the Amex majority opinion; and a surgical fix by Congress.

\section{An Antitrust Tale of WoE}

\section{A. The Origin of Antisteering}

Credit card networks, which emerged in their modern form in the mid- $20^{\text {th }}$ century, ${ }^{13}$ are platforms. Visa and Mastercard operate as networks connecting financial institutions that offer Visa- or Mastercard-branded credit cards to cardholders (through "issuing banks") with financial institutions that offer payment acceptance services to merchants (known as "acquiring banks"). ${ }^{14}$ By contrast, American Express interacts directly with both cardholders and merchants. ${ }^{15}$

When a cardholder uses a credit card, the merchant pays a fee. For Visa and Mastercard payments, this merchant fee is allocated among three parties: the cardholder's issuing bank; the merchant's acquiring bank; and the credit card network itself. ${ }^{16}$ For American Express payments, the merchant fee is generally retained in full by American Express. ${ }^{17}$ American Express's revenue stream depends primarily on this fee; those of Visa and Mastercard depend primarily on offering credit services to their cardholders, for which they charge an interest rate. ${ }^{18}$

As credit card use grew after the 1960s, American Express, Visa, and Mastercard competed with one another for both merchants and cardholders. ${ }^{19}$ By 1990, Amex accounted for $25 \%$ of the dollars processed by all the credit card networks. ${ }^{20}$ In response to American Express's expansion, Visa and Mastercard launched a series of marketing campaigns seeking to encourage cardholders to use their own cards instead, highlighting American Express's smaller network of merchants and its higher merchant fees. ${ }^{21}$ These campaigns were effective: for example, the District Court found that a "We Prefer Visa" campaign contributed to a 25-

\footnotetext{
${ }^{13}$ United States v. Am. Express Co., 88 F. Supp. 3d. 143, 160 (E.D.N.Y. 2015).

${ }^{14} \mathrm{Id}$. at $157 .{ }^{15} \mathrm{Id} .{ }^{16} \mathrm{Id}$. at 157.

${ }^{15} \mathrm{Id} .{ }^{16} \mathrm{Id}$. at 157.

${ }^{16} \mathrm{Id}$. at 157.

${ }^{17} \mathrm{Id}$.

${ }^{18} I d$. at 159.

${ }^{19} \mathrm{Id}$. at 161 .

${ }^{20} \mathrm{Id}$.

${ }^{21} I d$.
} 
$45 \%$ shift in card volume from American Express to Visa. ${ }^{22}$ By 1995 , American Express's share of dollars processed had dropped to $20 \%{ }^{23}$

American Express responded by introducing contractual restraints preventing merchants from steering customers to lower cost cards like Visa or Mastercard. ${ }^{24}$ These "antisteering" rules, which American Express refers to as "Non-Discrimination Provisions," prohibit merchants from "attempting to influence their customers' card choices" through any of a variety of monetary and non-monetary means. ${ }^{25}$ Rather than attempt to tempt merchants away with fee reductions, Visa and Mastercard instead followed suit, tightening their own antisteering rules. ${ }^{26}$ And with merchants now prohibited from steering away from American Express, Mastercard, or Visa, the three networks all implemented merchant fee increases. ${ }^{27}$

Discover tried offering lower merchant fees and, in 1999, led a marketing campaign to encourage merchants to steer customers to use their Discover card. ${ }^{28}$ But merchants informed Discover that their hands were tied because of antisteering provisions in their contracts with the other networks. ${ }^{29}$ Thus, Discover's discount-based challenge was effectively repelled. ${ }^{30}$

A decade later, in 2010, the U.S. Department of Justice ("DOJ") filed a complaint in the Eastern District of New York challenging Visa, Mastercard, and American Express's antisteering rules, alleging that all three credit card networks violated Section 1 of the Sherman Act by requiring merchants to agree to these provisions. ${ }^{31} \mathrm{Visa}$ and Mastercard settled with DOJ in 2011 and agreed to abandon their antisteering rules for a period of ten years. ${ }^{32}$ But American Express refused to follow suit. ${ }^{33}$ At the time, American Express was the largest single card issuer in the United

\footnotetext{
${ }^{22} I d$.

${ }^{23} I d$.

${ }^{24} I d$.

${ }^{25} I d$. at 165 .

${ }^{26} I d$.

${ }^{27} \mathrm{Id}$. at $201-02$.

${ }^{28}$ Brief for Discover Financial Services as Amicus Curiae Supporting Petitioners at 7, Ohio v, Am. Express Co. (Dec. 14, 2017) (No. 16-1454) (hereinafter "Discover Brief Amicus Curiae").

${ }^{29} I d$. at 8 .

${ }^{30} \mathrm{Id}$. at $8-9$.

${ }^{31}$ Final Judgment as to Defendants MasterCard International Incorporated and Visa Inc., United States v. Am. Express Co., No. CV-10-4496 (NGG) (RER) (E.D.N.Y. July 20, 2011), ECF No. 143 (hereinafter "Visa-MasterCard Settlement").

${ }^{32}$ Visa-MasterCard Settlement.

${ }^{33}$ Competitive Impact Statement at 14, United States v. Am. Express Co., No. CV-10-4496 (NGG) (RER) (E.D.N.Y. Oct. 4, 2010).
} 
States, and American Express-branded cards accounted for a significant share of credit card transaction volume. ${ }^{34}$

\section{B. District Court}

In 2015, following a seven-week bench trial, the District Court held that American Express's antisteering rules violated Section 1 of the Sherman Act. ${ }^{35}$ The court reasoned that the antisteering rules constitute non-price vertical restraints and as such should be adjudged under the rule of reason. ${ }^{36}$ The court applied a fairly traditional rule-of-reason framework. In step one, the plaintiff bears the burden of "demonstrating that the challenged restraints have had an adverse effect on competition as a whole in the relevant market." The plaintiff may do so directly, by "show[ing] an actual adverse effect on competition caused by the restraint in the relevant market, such as increased prices or a reduction in output," or indirectly, by "establishing that [the defendant] had sufficient market power to cause an adverse effect on competition" and that "there are other grounds to believe that the defendant's behavior will harm competition market-wide." ${ }^{37}$ In step two, the burden shifts to the defendant to offer "evidence of the procompetitive effects of their agreement." ${ }^{38}$ Finally, in step three, the burden shifts back to the plaintiff to "prove that any legitimate competitive benefits proffered by Defendants could have been achieved through less restrictive means." 39

At step one, the court held that the plaintiffs had established harm to competition through both direct and indirect evidence. In its analysis of the indirect evidence, the court followed an earlier Second Circuit decision ${ }^{40}$ in holding that American Express's platform operated in at least "two separate, yet deeply interrelated, markets": (1) a card issuance market, in which American Express and its competitors supplies services to cardholders, and (2) a network services market, in which American Express and its

\footnotetext{
${ }^{34}$ United States v. Visa USA, Inc., 344 F.3d 229, 237 (2d Cir. 2003). Visa-branded cards (issued by multiple banks) accounted for a larger share of all transactions. Amex was still the largest issuer at the time of the Supreme Court decision in Amex, but as of 2020 has fallen behind Chase. Top Issuers of General Purpose Credit Cards in the U.S., NILSON REPORT no. 1192 (Feb. 2021).

3588 F. Supp. 3d. at 143.

${ }^{36} I d$. at 169 .

${ }^{37} I d$. (internal citations and quotations omitted).

${ }^{38} \mathrm{Id}$. (internal citations and quotations omitted).

${ }^{39} \mathrm{Id}$. (internal citations and quotations omitted). Note that, unlike many other formulations of the rule of reason, the District Court did not also mention that, at this stage of the rule of reason, plaintiffs may also show that, on balance, the harms resulting from the restraints outweigh the procompetitive effects put forward by the defendant. See Continental T. V., Inc. v. GTE Sylvania Inc., 433 U.S. 36 (1977).

${ }^{40}$ Visa, 344 F.3d at 234.
} 
competitors supply acceptance services to merchants. ${ }^{41}$ Despite the separate nature of these two markets, the court cautioned that its analysis would "account for the two-sided features of the credit card industry in its market definition inquiry, as well as elsewhere in its antitrust analysis." 42

Examining these markets, the court concluded that American Express held market power in the market for network services provided to merchants, in which it enjoyed a share of $26.4 \% .{ }^{43}$ It chronicled evidence of concentration, high barriers to entry, and inelastic demand for use of American Express cards. ${ }^{44}$ The court concluded that the indirect evidence alone was sufficient to discharge the plaintiffs' burden. ${ }^{45}$

The court also evaluated the plaintiffs' direct-effects case thoroughly, focusing on the tendency of the antisteering rules to "suppress its network competitors' incentive to offer lower prices ... and resulting in higher profit-maximizing prices across the network services market. ${ }^{46}$ The court noted that, between 2005 and 2010, American Express had implemented a series of merchant fee hikes without losing a single large merchant, ${ }^{47}$ and that these merchant fee increases had not been accompanied by equivalent increases in cardholder rewards. ${ }^{48}$ The court highlighted the lack of merchant attrition in response to these price hikes as evidence of American Express's market power. ${ }^{49}$

American Express's antisteering rules promised even broader harms, by encouraging higher merchant fees for other cards, as demonstrated by Discover's failed "lowest-cost provider strategy" 50 and by the fact that, even after eliminating their antisteering rules, Visa and Mastercard had been able to raise their merchant fees with "virtual impunity" under the umbrella of

\footnotetext{
4188 F. Supp. 3d. at 151.

${ }^{42} \mathrm{Id}$. at 174 .

${ }^{43} I d$. at 188 (measuring market share by dollar value of transactions using credit cards). In the earlier Visa case, the Second Circuit found that Mastercard enjoyed market power with a market share of $26 \%$. See Visa, 344 F.3d at 240.

4488 F. Supp. 3d. at $188-95$.

${ }^{45}$ See id. at 212. The court's assessment of the restraints' anticompetitive tendency was entwined with its assessment of direct evidence of competitive harm. See id. at 208.

${ }^{46} I d$. at 209.

${ }^{47} \mathrm{Id}$. at 195.

${ }^{48} I d$. at 196.

${ }^{49} \mathrm{Id}$.

${ }^{50} \mathrm{Id}$. at 151 . See also id. at 210 ("The three major networks similarly felt no pressure to lower their own prices or otherwise respond to Discover's efforts in the late 1990s to build its share in the network services market by offering merchants prices well below those charged by its competitors. . . [t]he failure of Discover's low-cost provider strategy in the 1990s provides direct evidence of how antisteering rules like Defendants' NDPs impede modes of competition that likely would benefit consumers on both sides of the [credit card] platform.").
} 
American Express's rules. ${ }^{51}$ With no prospect of winning share through price competition, there was no reason for competitors to lower fees. ${ }^{52}$

The court did not ignore consumers on the other side of the platform. ${ }^{53}$ It held that the antisteering rules harmed customers on the other side of the platform as well, because inflated merchant fees are passed on as higher retail prices to all customers-American Express cardholders and noncardholders alike ${ }^{54}$ - and most of these customers do not receive sufficient cardholder benefits to offset the harms. ${ }^{55}$

The plaintiffs having satisfied their burden with both direct and indirect evidence, the burden shifted to American Express to prove that the restraints had procompetitive benefits. American Express claimed two types of procompetitive justifications for its antisteering rules, but neither was accepted. First, American Express argued that the rules were "critical" to preserve "welcome acceptance" of its cards and to maintain its unique business model, which in turn drove competition in the network services market. ${ }^{56}$ In particular, American Express claimed that if merchants were permitted to "discriminate" at the point of sale by encouraging its cardholders to use another form of payment, its cardholders would be less likely to use their cards, not only at the steering merchant, but also at other merchants. ${ }^{57}$ The District Court determined that this argument—which effectively painted freedom from price competition as a benefit rather than a harm - was not cognizable as a matter of law because it is "axiomatic that the federal antitrust laws were enacted for the protection of competition, not competitors." 58

The District Court also rejected the argument that its antisteering rules prevented merchants from free riding on its cardholder investments and rewards. The court pointed out that a cardholder would not switch to another card unless the cardholder believed that "what the merchant offers is of greater value than the rewards received for using an American Express

\footnotetext{
${ }^{51}$ Id. at 202; see also id. at 216 ("Visa and Mastercard, for instance, were able to increase their average all-in merchant rates through a variety of means by more than $20 \%$ from 1997 to 2009 , without fear of other networks undercutting their prices in order to gain share.").

${ }^{52} \mathrm{Id}$. at 150 .

${ }^{53}$ As John Newman noted at the time, the judge mentioned cardholders "a whopping 239 times." John Newman, Ohio v. American Express Is the Antitrust Case of the Century - So Why Isn't Anyone Talking About It?, CONCURREnTIALISTE (Feb. 26, 2018).

5488 F. Supp. 3d. at 208.

${ }^{55} \mathrm{Id}$. at 215 .

${ }^{56} \mathrm{Id}$. at 225 .

${ }^{57} \mathrm{Id}$. at 225 .

${ }^{58} \mathrm{Id}$. at 227 .
} 
card." 59 With respect to American Express's claimed investments in data analytics services provided to merchants, the court noted that concerns about free riding were reduced given that American Express itself sold those services separately from network services. ${ }^{60}$ Finally, the Court rejected American Express's argument that the restraints were necessary to prevent merchants from free-riding on American Express's investments to enhance its own brand. ${ }^{61}$ Indeed, American Express's own survey data showed that its "credentialing" effect - the halo of prestige that acceptance of American Express cards purportedly confers on a merchant-actually trailed that of its competitors and, in any event, was not the result of specific investment by American Express and so was not likely to be impacted by free-riding. ${ }^{62}$

Lacking any plausible procompetitive benefits, American Express's antisteering rules unlawfully restrained competition in the network services market, and so violated Section 1.

\section{Court of Appeals}

The District Court's analysis did not survive review by the U.S. Court of Appeals for the Second Circuit, which took a profoundly different view of the record, the law, and applicable economic principles.

Distinguishing its own separate-markets approach in the earlier Visa case, ${ }^{63}$ the court held that a single relevant market ought to be defined to include both the cardholder- and merchant-services sides of the platform. ${ }^{64}$ The court proceeded to outline the types of evidence that would have been sufficient to satisfy the plaintiff's initial burden under the rule of reason in this single, two-sided, market: first, evidence of reduced output (i.e., cardholders engaging in fewer credit card transactions than they otherwise would); second, evidence of reduced quality (i.e., card services worse than they would otherwise have been); or, third, evidence of supracompetitive pricing (i.e., American Express's net, or overall, pricing above competitive levels). ${ }^{65}$

\footnotetext{
${ }^{59} I d$. at 238 .

${ }^{60} \mathrm{Id}$. at 236.

${ }^{61} \mathrm{Id}$. at 238 .

${ }^{62} \mathrm{Id}$. at 238 .

63838 F.3d at 198 ("Unlike the contested conduct in this case the contested conduct in Visa occurred not among different sides of the same network platform, but rather between the platforms themselves.").

${ }^{64}$ Id.

${ }^{65} \mathrm{Id}$. at $205-206$.
} 
Applying this standard, the court concluded - in a strikingly brief analysis that purported to disturb none of the District Court's careful factual findings - that there was no evidence of diminished quality, and without a reliable measure of Amex's net price, plaintiffs could not show that that price was supracompetitive. ${ }^{66}$ And regarding output, the court noted that transaction volume had increased across the credit card industry throughout the relevant time, which it viewed as evidence that American Express's rules were procompetitive. ${ }^{67}$ As a result, the plaintiffs had failed to meet their "initial burden ... to show that the [antisteering rules] made all Amex consumers on both sides of the platform-i.e., both merchants and cardholders-worse off overall." ${ }^{68}$ Concluding that the plaintiffs had accordingly failed to establish a prima facie case, the appellate court remanded with instructions to enter judgment in favor of American Express.

\section{Supreme Court}

DOJ elected not to appeal the Second Circuit's decision, but eleven state attorneys general pressed on, appealing the direct-evidence case only. ${ }^{69}$ In a relatively brief opinion, the majority endorsed the Second Circuit's holding and much of its essential reasoning. ${ }^{70}$ The Court's critical holdings are summarized briefly here and evaluated in Part II.

First, the Court indicated that a formal market definition was a necessary element of the antitrust analysis in cases involving vertical theories of harm, noting - apparently without irony — that "[1] egal presumptions that rest on

\footnotetext{
${ }^{66} I d$. at 206. Of course, while the District Court did not explicitly calculate a net-price, its opinion includes extensive discussion of Amex's pricing history and concluded that "by disrupting the pricesetting mechanism ordinarily present in competitive markets, the NDPs reduce American Express's incentive - as well as those of Visa, Mastercard, and Discover - to offer merchants lower merchant fees and, as a result, they impede a significant avenue of horizontal interbrand competition in the network services market." 88 F. Supp. 3d. at 207-08.

67 "Increased investment in cardholder rewards has accompanied a dramatic increase in transaction volume across the entire credit-card industry ... This evidence of increased output is not only indicative of a thriving market for credit-card services but is also consistent with evidence that Amex's differentiated closed-loop model, supported by its NDPs, has increased rather than decreased competition overall within the credit-card industry." 838 F.3d at 206. The Court made no effort to adjust for the growth of the economy in general, or card-favoring commerce (including e-commerce!) in particular, over that time.

${ }^{68} \mathrm{Id}$. at 205.

${ }^{69}$ Petition for Writ of Certiorari, Ohio v. Am. Express Co., 138 S. Ct. 2274 (No. 16-1454). See also 138 S. Ct. at 2287.

${ }^{70}$ Justice Thomas wrote for the Court on behalf of five Justices, joined by Chief Justice Roberts and Justices Kennedy, Alito, and Gorsuch; Justice Breyer dissented for himself and for Justices Ginsburg, Sotomayor, and Kagan.
} 
formalistic distinctions rather than actual market realities are generally disfavored in antitrust law."

Second, the Court followed the Second Circuit in holding that the appropriate market definition in Amex encompassed both consumer- and merchant-facing sides of the card platform. ${ }^{72}$ The Court appeared to believe that this was required in order to capture the reality that activities on the two sides were related and to reflect that a price increase on one side alone did not necessarily mean or imply an increase in overall price. ${ }^{73}$

But the Court cabined its approach: only some two-sided markets would be treated for market definition purposes in this way. The "two sides, one market" approach was appropriate only for "transaction platforms", defined as platform businesses that "facilitate a single, simultaneous transaction between participants."74 "The key feature" of such businesses, the Court explained, was that "they cannot make a sale to one side of the platform without simultaneously making a sale to the other." 75 A single market definition was appropriate, in the Court's view, because: (1) activity on the two sides was always joint, simultaneous, and in fixed proportions; (2) the two sides were connected by "more pronounced" network effects and interrelation of demand and pricing; and (3) "[o]nly other two-sided platforms can compete with a two-sided platform for transactions."76

The Court also held that the plaintiffs had failed to show prima facie evidence of harm in this unified market. The Court held that to do so plaintiffs would have had to show that the antisteering rules: (a) increased the overall price of credit-card transactions above a competitive level, (b) reduced output (i.e., the number of credit-card transactions), or (c) otherwise stifled competition in the credit card market. ${ }^{77}$ According to the Court, the price evidence did not imply that credit card transactions were more expensive, overall, than they would be in a competitive market. ${ }^{78}$

\footnotetext{
${ }^{71}$ Id. at 2285 (quoting Eastman Kodak Co. v. Image Technical Services, Inc., 504 U.S. 451, 466-67 (1992)). Michael Katz and Douglas Melamed have also pointed out this incongruence. Michael L. Katz \& A. Douglas Melamed, Competition Law as Common Law: American Express and the Evolution of Antitrust, 168 U. PeNN. L. ReV. 2061 (2020).

${ }^{72} I d$. at 2286.

${ }^{73} \mathrm{Id}$. at $2285-86$.

${ }^{74} \mathrm{Id}$. at 2286.

${ }^{75} \mathrm{Id}$. at 2280 (emphasis added).

${ }^{76} \mathrm{Id}$. at 2286-87. The Court's earlier holding in Times-Picayune Publishing Co. v. United States, 345 U.S. 594 (1953), that the advertiser and reader sides of a newspaper platform should be analyzed separately, was distinguished on the ground that it did not involve one of these transaction platforms and its network feedback effects were one-directional. $138 \mathrm{~S}$. Ct. at 2280.

${ }^{77} \mathrm{Id}$. at $2287-88$.

${ }^{78} \mathrm{Id}$. at 2288 .
} 
Evidence that American Express had increased its merchant fees was inadequate because the increased prices "reflect increases in the value of its services and the cost of its transactions, not an ability to charge above a competitive price." 79 The Court pointed out that Visa and Mastercard's merchant fees had continued to increase after their consent agreements, including at merchant locations where American Express was not accepted. ${ }^{80}$ In the majority's view, satisfactory output evidence was not forthcoming either, as the overall volume of credit-card transactions had grown by 30 percent from 2008 to $2013 .{ }^{81}$ The Court was also untroubled by the tendency of antisteering rules to suppress fee competition. ${ }^{82}$ The Court indicated that merchant fees had in fact decreased by over half since the 1950 s. $^{83}$

Finally, the Court noted in closing, there was "nothing inherently anticompetitive about Amex's antisteering provisions." 84 The Court revived American Express's efficiency argument—rejected by the District Court as ungrounded in evidence - that the antisteering provisions prevented merchants from undermining cardholders' expectation of "welcome acceptance." 85

In dissent, Justice Breyer's began by explaining that market definition is not required in cases featuring direct evidence of anticompetitive effects, ${ }^{86}$ because "proof of actual adverse effects on competition is, a fortiori, proof of market power." ${ }^{87}$ Because plaintiffs had demonstrated that American Express was able to raise merchant prices repeatedly without any significant

\footnotetext{
${ }^{79} I d$.

${ }^{80} I d$. The Court did not discuss why Visa and Mastercard would have incentives to depart from uniform pricing to offer lower merchant fees at non-American Express locations or whether that type of price differential would have been practical to implement. The issue of parallel conduct among the three networks is discussed in Section III.

${ }^{81} I d$.

${ }^{82} I d$.

${ }^{83}$ Id. The Court's citation to the District Court here pointedly omitted evidence from the same page that, "[w]hen Plaintiffs' economics expert controlled for the changing composition of Amex's merchant base, he found that the network's average effective merchant fee had, in fact, increased slightly over time." 88 F. Supp. at 203.

${ }^{84} 138$ S. Ct. at 2289.

${ }^{85}$ Id. See also John Newman, Ohio v. American Express: The Good, The Bad, and the Ugly, CONCURRENTIALISTE (July 16, 2018) (noting that "Justice Thomas came close to outright misrepresenting the trial record" on this point).

${ }^{86} 138$ S. Ct. at 2291 (citing FTC v. Ind. Fed'n of Dentists, 476 U.S. 447, 459 (1986) (citing 7 PhILLIP E. AreEDa, ANTItrust LAW 1511, p. 429 (3d ed. 1986))).

${ }^{87}$ Id. at 2297.
} 
loss of business, formal market definition using indirect evidence was an unnecessary analytical exercise. ${ }^{88}$

Justice Breyer also rejected the majority's definition of a single two-sided transaction platform market. While acknowledging that such platforms offer different products or services to different groups of customers whom the "platform" connects in simultaneous transactions, ${ }^{89}$ Breyer explained that each of those features also describes many other products and services that have long been analyzed using traditional market definition principles. ${ }^{90}$

Finally, the dissent protested, the evidence of harm assembled here was more than sufficient. The District Court had expressly concluded: (1) that all consumers, not just Amex cardholders, paid higher retail prices as a result of the challenged practices; (2) that the restraints excluded competition and permitted repeated increases in merchant fees; and (3) that consumers were denied opportunities to accept incentives that merchants might otherwise have offered to use less-expensive cards. "91 "I should think that, considering step 1 [of the rule of reason] alone," concluded Justice Breyer, "there is little more that need be said." 92

\section{Diagnosis and Prescription: Amex's Errors, and a Better Approach}

The analytical errors of Amex were substantial and unnecessary: a better approach was available. It appears that the Court was motivated by a fear that antitrust analysis could too quickly condemn platform conduct that was beneficial overall but harmful to consumers on a single side of the platform, and that the Court believed that it was necessary to distort other basic principles of antitrust analysis - including those relating to market definition and burdens of proof - in order to protect against this risk. ${ }^{93}$

But the Court instead could and should have simply held that, in a welldefined but limited subset of platform cases, multi-market balancing of effects may be appropriate..$^{94}$ Doing so would have candidly acknowledged

${ }^{88}$ Id. at 2294.

${ }^{89} \mathrm{Id}$. at 2298.

${ }^{90} \mathrm{Id}$.

${ }^{91} I d$.

${ }^{92} I d$.

${ }^{93}$ This concern would be generally consistent with the modern Court's clear preoccupation with false positives in antitrust adjudication. See, e.g., Verizon Communications Inc. v. Law Offices of Curtis V. Trinko, LLP, 540 U.S. 398, 414 (2004) ("The cost of false positives counsels against an undue expansion of $\S 2$ liability.").

94 The Court also pointedly avoided the issue of multi-market balancing in Nat'l Collegiate Athletic Ass'n v. Alston, 594 U.S. _ (2021), where it raised but declined to address the argument that "a court 
the relevant normative and legal considerations, while preserving the clarity and integrity of other antitrust principles that now stand needlessly compromised.

\section{A. Diagnosis: Three Errors}

\section{An Unforced Error: Requiring Circumstantial Evidence of Market Definition in a Direct-Evidence Case}

The most bizarre of the Amex Court's errors was its odd insistence on a formal market definition and market share evidence to establish market power. It has long been hornbook law that this is not a necessary component of modern antitrust analysis, and much modern antitrust scholarship encourages courts and agencies to move beyond the strictures of market definition where it is possible to do so. ${ }^{95}$

As the District Court correctly pointed out, plaintiffs have long had two avenues to satisfy their burden to demonstrate anticompetitive effects under the first step of the rule of reason in both vertical and horizontal cases. Plaintiffs may either (a) provide direct evidence of anticompetitive effects, or (b) provide circumstantial (or indirect) evidence consisting of (i) demonstrated market power, and (ii) additional indicia that the conduct is likely to harm competition. ${ }^{96}$

should not "trade off "sacrificing a legally cognizable interest in competition in one market to better promote competition in a different one" and that "review should instead be limited to the particular market in which antitrust plaintiffs have asserted their injury." Alston, 594 U.S. at (slip op. at 15). Of course, the Court appeared to reject the idea of multi-market balancing, at least in merger cases, in Philadelphia National Bank, See generally infra § II.B.1.

${ }^{5}$ See, e.g., Louis Kaplow, Market Definition: Impossible and Counterproductive, 79 ANTITRUST L.J. 361 (2013); Adriaan ten Kate \& Gunnar Niels, The Relevant Market: A Concept Still in Search of a Definition, 5 J. Competition L. \& Econ. 297, 298 (2009); Steven C. Salop, The First Principles Approach to Antitrust, Kodak, and Antitrust at the Millenium, 68 ANTITRUST L.J. 187 (2000). See also, Joseph Farrell \& Carl Shapiro, Antitrust Evaluation of Horizontal Mergers: An Economic Alternative to Market Definition, 10 B.E. J. TheORETICAL ECON. (2010) ("Product differentiation can make defining the relevant market problematic, notably because products must be ruled 'in' or 'out,' creating a risk that the outcome of a merger investigation or case may turn on an inevitably artificial linedrawing exercise").

${ }^{96}$ The District Court in Amex followed the long-standing approach of many other courts. See, e.g., United States v. Microsoft Corp., 253 F.3d 34, 51 (2001); Toys "R” Us, Inc. v. FTC, 221 F.3d 928, 937 (7th Cir. 2000); Rebel Oil Co. v. Atl. Richfield Co., 51 F.3d 1421, 1434 (9th Cir. 1995); Cont'1 Airlines, Inc. v. United Air Lines, Inc., 120 F. Supp. 2d 556, 567 (E.D. Va. 2000); In re Loestrin 24 Fe Antitrust Litig., 433 F. Supp. 3d 274, 300 (D.R.I. 2019); see also Re/Max Int'1, Inc. v. Realty One, Inc., 173 F.3d 995, 1016 (6th Cir. 1999); but see Republic Tobacco Co. v. N. Atl. Trading Co., 381 F.3d 717, 737 (7th Cir. 2004) (noting that "[i]t may be that, in a proper case alleging vertical restraints, a direct anticompetitive effects analysis could be used to show market power," but suggesting that the "rough contours" of a definition should always be required). The agencies have also endorsed this view. See U.S. Department of Justice \& Federal Trade Commission, Horizontal Merger Guidelines (Aug. 2010). 
Market definition can play an important role in an indirect-evidence case because one way to demonstrate market power is to show that the defendant has a substantial share in a relevant market. ${ }^{97}$ But market definition is an analytical step designed to screen for the ability to inflict harm - that is, market power - and it is widely recognized that direct evidence of actual anticompetitive effects makes it unnecessary to prove such power indirectly. ${ }^{98}$ Accordingly, courts have long held that direct evidence of anticompetitive effects necessarily implies the existence of sufficient market power to cause such effects. ${ }^{99}$

Before Amex, the Supreme Court itself had expressly recognized this principle. In Indiana Federation of Dentists, a challenge to a decision by a dentists' professional organization to restrict insurers' access to dental xrays, the Court held that "the finding of actual, sustained adverse effects on competition" obviated the need for formal market definition. ${ }^{100}$ But the Amex Court limited Indiana Federation of Dentists to horizontal cases, and held that formal market definition is indispensable in vertical cases. ${ }^{101}$ "Vertical restraints," the majority explained, "often pose no risk to competition unless the entity imposing them has market power, which cannot be evaluated unless the Court first defines the relevant market."102 For this proposition, the Court cited its decision in Leegin Creative Leather Products, Inc. v. PSKS, Inc., ${ }^{103}$ as well as Judge Easterbrook's article Vertical Arrangements and the Rule of Reason. ${ }^{104}$

But these sources simply noted the importance of evaluating market power. They did not endorse a requirement of formal market definition. In fact, Judge Easterbrook's article specifically stated that "[a]n inquiry into market power does not entail the definition of a 'market,' a subject that has bedeviled the law of mergers. Market definition is just a tool in the investigation of market power." 105 Indeed, direct evidence is normally

\footnotetext{
${ }^{97}$ P. Areeda \& H. Hovenkamp, Fundamentals of Antitrust Law $\S 5.03$ [A] (4th ed. 2017).

${ }^{98}$ See, e.g., FTC v. Facebook, Inc., No. 20-3590 (JEB) (D.D.C. June 28, 2021).

99 Justice Breyer's dissent correctly stated this principle. 138 S. Ct. at 2997 (2018) (Breyer, J., dissenting) ("The District Court's findings of actual anticompetitive harm from the nondiscrimination provisions thus showed that, whatever the relevant market might be, American Express had enough power in that market to cause that harm. There is no reason to require a separate showing of market definition and market power under such circumstances."). But see, e.g., Daniel A. Crane, Market Power Without Market Definition, 90 Notre Dame L. Rev. 31 (2014) (noting confusion regarding the evidence from which direct effects can in fact be inferred).

${ }^{100}$ See Ind. Fed'n of Dentists, 476 U.S. at 461.

101138 S. Ct. at 2285 n. 7.

102 Id.

103551 U.S. 877 (2007).

${ }^{104}$ Frank H. Easterbrook, Vertical Arrangements and the Rule of Reason, 53 ANTITRUST L.J. 135, 160 (1984).

${ }^{105}$ Id. at 160 (emphasis added); see also, e.g., Katz \& Sallet, supra note 3, at 2152.
} 
considered more reliable than circumstantial evidence based on market shares. ${ }^{106}$

Nor did the argument make economic sense. The Court's central claimthat a critical difference exists between horizontal and vertical cases, in that vertical restraints do not present any risk to competition unless the entity imposing them has market power - is no difference at all. Horizontal restraints also do not present any risk to competition unless the participants collectively enjoy market power. Moreover, direct evidence of market power has often been used by courts of appeal in vertical cases. ${ }^{107}$ And the Supreme Court has never required a heightened burden of proof of harm, even for intrabrand vertical restraints. ${ }^{108}$ Amex involved a restraint that directly reduced interbrand competition, a category of agreement widely understood to present competitive dangers.

Ultimately, the market-definition requirement was an unforced error. The point of the rule of reason is to allow for careful and neutral examination of evidence and theory specific to a challenged restraint. ${ }^{109}$ While antitrust cases litigated under the rule of reason are already famously challenging for plaintiffs, ${ }^{110}$ if the Court was determined to make them harder still, it could have done so directly by expressly imposing an elevated burden of proof,

\footnotetext{
106 See, e.g., Horizontal Merger Guidelines $§ 4$ ("Such evidence also may more directly predict the competitive effects of a merger, reducing the role of inferences from market definition and market shares."); see also, e.g., Tim Wu, The Supreme Court Devastates Antitrust Law, N.Y. Times (June 26, 2018) ("[T] he court put theory ahead of practice in an absurd way: Even though, in practice, American Express hurt competition and inflicted harm on consumers, the court concluded, the company was not, in theory, powerful enough to do so. The logic is ridiculous: You could just as easily say that robbing banks is economically irrational, given the risks involved, and therefore it does not happen.”).

${ }^{107}$ See supra note 96.

${ }^{108}$ See, e.g., Leegin, 551 U.S. 877 (2007); GTE Sylvania, 433 U.S. 36; State Oil Co. v. Khan, 522 U.S. 3 (1997).

${ }^{109}$ Khan, 522 U.S. at 10.

${ }^{110}$ See, e.g., Michael A. Carrier, The Rule of Reason: An Empirical Update for the $21^{\text {st }}$ Century, 16 GeO. MASON L. REV. 827, 828 (2009) ("Courts dispose of 97\% of [rule of reason] cases at the first stage, on the grounds that there is no anticompetitive effect. They balance in only $2 \%$ of cases."). As Erik Hovenkamp aptly puts it: "there simply isn't any room for a large swath of plaintiff-favoring errors, because plaintiffs almost never win in the first place." Erik Hovenkamp, Platform Antitrust, 44 J. Corp. L. 713, 752 (2019)
} 
such as "clear and convincing evidence" 111 or "clear showing." 112 If the Court believed that a two-sided market definition was necessary to achieve the desired effects analysis, that too is mistaken, as we discuss below.

2. Market Definition: Breaking the Substitutability Principle

Having determined that a formal market definition was necessary, the Court next turned to what that definition ought to be. The traditional touchstone for this exercise is the principle of demand-side substitutability. The Supreme Court long ago instructed that "[ $\mathrm{t}]$ he outer boundaries of a product market are determined by the reasonable interchangeability of use or the cross-elasticity of demand between the product itself and substitutes for it." ${ }^{113}$ In other words, a market contains the relevant product or service, plus whatever other products and services are reasonably substitutable for it. ${ }^{114}$ Failure to define a market by reference to this principle is normally fatal to an antitrust claim. ${ }^{115}$

The logic underlying this approach is simple. Market definition is an effort to identify market power by identifying the set of competitive constraints that would make it unprofitable for a firm or group of firms to impose supracompetitive prices or other worsened terms of dealing. ${ }^{116}$ Courts and agencies test whether an actual or hypothetical monopolist supplier of a particular set of products or services would be able profitably to implement a significant price increase above competitive levels. ${ }^{117}$ This exercise should be conducted with an eye to the specific competitive concerns at

\footnotetext{
${ }^{111}$ See, e.g., Monsanto Co. v. Spray-Rite Serv. Corp., 465 U.S. 752, 764 (1984) (requiring that antitrust plaintiff in vertical price-fixing case "present direct or circumstantial evidence that reasonably tends to prove that the manufacturer and others had a conscious commitment to a common scheme designed to achieve an unlawful objective") (internal quotations omitted); Matsushita Elec. Indus. Co. v. Zenith Radio Corp., 475 U.S. 574, 588 (1986) (requiring plaintiff to "show that the inference of conspiracy is reasonable in light of the competing inferences of independent action or collusive action that could not have harmed respondents"). In both cases the court required that the plaintiff show evidence "that tends to exclude the possibility" that the alleged conspirators acted independently. Matsushita, 475 U.S. at 588 (citing Monsanto, 465 U.S. at 764).

112 See, e.g., United States v. Philadelphia Nat'l Bank, 374 U.S. 321, 363 (1963).

${ }_{113}$ Brown Shoe Co. v. United States, 370 U.S. 294, 325 (1962). See also, e.g., United States v. E. I. du Pont de Nemours \& Co., 351 U.S. 377, 404 (1956); Sharif Pharmacy, Inc. v. Prime Therapeutics, LLC, 950 F.3d 911, 918 (7th Cir. 2020); Lifewatch Servs. Inc. v. Highmark Inc., 902 F.3d 323, 337 (3d Cir. 2018).

${ }^{114}$ NCAA v. Bd. of Regents of Univ. of Oklahoma, 468 U.S. 85, 111 (1984).

115 See, e.g., Shah v. VHS San Antonio Partners, LLC, 985 F.3d 450, 455 (5th Cir. 2021) ("Shah's proposed relevant market does not encompass all interchangeable substitute products because it does not include the two non-BHS facilities that the BHS parties contend serve as viable alternatives to BHS facilities.").

${ }^{116}$ See, e.g., Jonathan B. Baker, Market Definition: An Analytical Overview, 74 AnTITRUST L. J. 129 (2007).

117 See Horizontal Merger Guidelines $₫ 4.1$.
} 
issue in each individual case. Thus, different theories of harm might imply different market definitions, even in the same antitrust case, but demandside substitutability remains central. ${ }^{118}$

Even the handful of "special" market definition tools derive from demandside substitutability. "Cluster" markets, for example, are aggregations of multiple traditionally-defined markets, treated together, shorthand-style, for analytical convenience (e.g., various different outpatient services supplied by the same hospitals under the same competitive conditions). 119 "Bundle" markets exist when a consumers demand a set of products or services together and where substitution involves the entire set (e.g., gloves, silverware sets, or automobiles). ${ }^{120}$ Likewise, courts sometimes define "price discrimination" markets that distinguish among customers by reference to differences in their ability or incentive to turn to substitute products or services. ${ }^{121}$ Finally, "supply-side substitution" may inform market definition in a limited way, by including in a relevant market defined on the basis of substitution those firms that do not currently produce reasonable demand-side substitutes, but could do so rapidly and at low cost. ${ }^{122}$ None of these variants diminishes the primacy of demand-side substitutability. ${ }^{123}$ As the District Court also noted, courts had applied the substitutability principle to credit card market definition in previous cases. $^{124}$

\footnotetext{
118 Steven C. Salop, The First Principles Approach to Antitrust, Kodak, and Antitrust at the Millenium, 68 Antitrust L.J. 187 (2000). See also Gregory J. Werden, Four Suggestions on Market Delineation, 37 ANTITRUST BULL. 107, 108-12 (1992) ("Assuring that markets are suitable for the purposes to which they are put requires that a preliminary step be taken before market delineation. This step is the identification of who might exercise market power, against whom it might be exercised, and how it might be exercised."). See, e.g., Olin Corp. v. FTC, 986 F.2d 295, 1299, 1301 (9th Cir. 1993); Staley v. Gilead Sciences, Inc., 446 F. Supp. 3d 578, 616 (N.D. Cal. 2020) ("[I]t is not unreasonable for Plaintiffs to have identified two different product markets because they have claimed harm to competition in two different ways.").

${ }^{119}$ See Krisha A. Cerilli, Staples / Office Depot: Clarifying Cluster Markets, ComPeTITION PoL'y InT'L (Aug. 2016).

${ }^{120}$ Kevin Hahm \& Loren K. Smith, Clarifying Bundle Markets and Distinguishing Them from Cluster Markets, ANTITRUST SOURCE (Feb. 2021).

${ }^{121}$ See, e.g., FTC v. Sysco Corp., 113 F. Supp. 3d 1, 39 (D.D.C. 2015) ("The concern underlying price discrimination markets is that certain types of captured or dedicated customers could be targeted for monopolist pricing even if a price increase for all customers would not be profitable.").

${ }^{122}$ See, e.g., FTC v. RAG-Stiftung, 436 F. Supp. 3d 278, 293-94 (D.D.C. 2020); Horizontal Merger Guidelines § 5.1 (Aug. 2010).

${ }^{123}$ Likewise, in other cases involving complementary products and competitive harm-including tying cases - antitrust courts and agencies do not define a single market to include both the tying and tied products. See, e.g., Jefferson Parish Hosp. Dist. No. 2 v. Hyde, 466 U.S. 2 (1984).

${ }^{124}$ In the early 2000s, the DOJ successfully challenged Visa and MasterCard's exclusivity rules, which prohibited their member banks from issuing American Express cards or Discover cards. Visa, 344 F.3d at 234. The Second Circuit affirmed the District Court's conclusion on relevant product market that
} 
The Amex majority started from the broad proposition that market definition is intended to reflect "the area of effective competition," that is, the "arena within which significant substitution in consumption or production occurs," taking account of "commercial realities." 125 The Court then defined a single "two-sided" market encompassing both services to cardholders and services to merchants, even though services to cardholders are not substitutable for services to merchants. ${ }^{126}$ The Court reasoned that indirect network effects required assessment of both sides of the platform in order to "accurately assess competition." 127 Due to these network effects, the majority cautioned, a price increase on one side did not necessarily imply an overall increase in the cost of the platform's services without testing for an offsetting beneficial effect on the other side of the platform. ${ }^{128}$

Indirect network effects clearly are important to the functioning of a platform like Amex, or any other two-sided platform. Likewise, an antitrust assessment should accurately reflect the nature and scope of any such effects. But these propositions do not require or justify combining both sides of the platform into a single antitrust market.

Consider the observation that prices and demand on the two sides of the platform were interrelated. It is true that if a platform serves two types of customers who each use the platform to transact with customers of the other type, then an increase in prices to one type could reduce demand for the platform's services from both types of customers through a negative feedback loop, limiting the profitability of such an increase. ${ }^{129}$

Thus, the Court was correct to point out that a price increase to customers on one side of a platform does not necessarily imply overall competitive harm, but that observation does not compel a novel approach to market definition. That a nominal price increase could have either a benign or a sinister explanation is not unique to multi-sided platforms; it is a common phenomenon. More generally, the relevant market definition need not

there are "two interrelated, but separate, product markets": (1) "the general purpose card market, consisting of the market for charge cards and credit cards," and (2) "the network services market for general purpose cards." Id. at 238-39. As the District Court explained, "general purpose card network services ... "constitute a product market because merchant consumers exhibit little price sensitivity and the networks provide core services that cannot reasonably be replaced by other sources." Id.

125138 S. Ct. at 2285. Cf. E. I. du Pont de Nemours \& Co., 353 U.S. at 593 ("area of effective competition”); Brown Shoe Co., 370 U.S. at 336 (1962) (geographic market must correspond to "commercial realities").

${ }^{126}$ Id. at 2287.

${ }^{127} I d$. As discussed later, the Court also erred by saying that "[o]nly other two-sided platforms can compete with a two-sided platform for transactions."

${ }^{128} I d$. at 2286.

${ }^{129} \mathrm{Id}$. at 2285 . 
include all business activity that could affect price (or output, quality, innovation, etc.). For example, a change in the price of a product or service could result from a change in the supply or price of a complementary good, but antitrust analysis has never for that reason included complements in the relevant market. ${ }^{130}$

Worse still, the Court's approach compromises the analytical function of the market definition exercise. ${ }^{131}$ As Jonathan Sallet and Michael Katz have pointed out, a separate-markets approach allows more precise measurement of competitive conditions, which may differ significantly from one side of a platform to another. ${ }^{132}$ For example, an ad-supported newspaper may be the only newspaper in town, but might compete on the advertising side with other forms of advertising, as explained in Lorain Journal. ${ }^{133}$ Aggregation of distinct groups of consumers into a single market impairs rather than facilitates granular assessment of competitive realities and thus undermines the utility of market definition. ${ }^{134}$

\section{An Illogical Limiting Principle: Transaction Platforms}

In what seems to be an effort to cabin the broader reach of its reasoning and to distinguish its own earlier cases, ${ }^{135}$ the Court confined its novel approach to a special subset of platforms -- "transaction platforms" - where merchants and cardholders use the platform's payment services jointly, simultaneously, and in fixed proportions. ${ }^{136}$ Such transaction platforms "exhibit more pronounced indirect network effects and interconnected pricing and demand" than other platforms and, according to the Court,

\footnotetext{
130 See Jonathan B. Baker, Market Definition: An Analytical Overview, 74 AntiTRust L. J. 129, 134 n.30 (2007) ("[T] he significance for competitive effects of demand complementarities should not be accounted for in the market definition step of the analytical process . . . Rather, the significance of demand complementarities should be accounted for in the later analysis of competitive effects."). See also Steven Salop, The First Principles Approach to Antitrust, Kodak, And Antitrust at the Millennium, 68 ANTITRUST L. J. 187 (2000).

131138 S. Ct. at 2285 n. 7 .

132 Michael Katz \& Jonathan Sallet, Multisided Markets and Antitrust Enforcement, 127 YALE L.J. 2142, 2158 (2018) ("As demonstrated for both advertising-supported media platforms and transaction platforms, the single-market approach fails to accurately account for product substitution and competitive conditions in multisided platform industries.").

133342 U.S. 143 (1951).

${ }^{134}$ See, e.g., FTC v. Indiana Fed. of Dentists, 476 U.S. 447, 460 (1986) (purpose of market definition is to "determine whether an arrangement has the potential for genuine adverse effects on competition"); Daniel Francis \& Jay Ezrielev, Disaggregating Market Definition: AmEx and a Plural View of Market Definition, 98 Neb. L. J. 460, 479 (2019) ("If the defendant cannot injure the competitive process, there is no need to go further and dig into the complexities and burdens of working out whether it has in fact done so.").

${ }^{135}$ Such cases include Lorain Journal as well as Times-Picayune, 345 U.S. 594.

136138 S. Ct. at 2286.
} 
supply only one product that is jointly consumed by both types of consumers. ${ }^{137}$

However, the concept of "transaction platforms" as a limiting principle leaves much to be desired. ${ }^{138}$ Many platforms exhibit indirect network effects of some kind. ${ }^{139}$ Non-transaction platforms with significant indirect network effects are legion: in the digital economy, these include content streaming and sharing platforms of all kinds; in the brick-and-mortar economy, one need look no further than economists' standard example of heterosexual singles bars. ${ }^{140}$ In those cases, indirect network effects may play a very important - even indispensable - role in appraising competitive effects. The Court offered no explanation why "transaction platforms" should be treated as a special category for the purpose of effects assessment. And, of course, the "share of transactions" would be identical regardless of whether transactions were counted on one side or both.

Moreover, even credit card platforms are not pristine transaction platforms as defined by the Court. Credit card networks provide competitively relevant membership services that are not consumed jointly, including revolving credit, entertainment benefits, and information services to cardholders, and analytic services to merchants. ${ }^{141}$ Thus, it seems that American Express's own services were not consumed by cardholders and merchants in a purely joint and simultaneous fashion. Thus, distinguishing a two-sided "transaction platform" from other platforms seems destined to be a wellspring of confusion-and litigation.

The Court was equally misguided in commenting that "[o]nly other twosided platforms can compete with a two-sided platform for transactions." 142 For example, a two-sided booking platform like Hotels.com, which would appear to satisfy the Court's definition of a transaction platform, may

\footnotetext{
${ }^{137} I d$.

${ }^{138}$ Nevertheless, despite the economics, this distinction may play a helpful role in understanding the limits of the Amex holding itself, as we suggest below. See infra $\S$ II.B.

139 See, e.g., Gunnar Niels, Transaction Versus Non-Transaction Platforms: A False Dichotomy In Two-Sided Market Definition, 15 J. COMPETITION L. \& ECON. 327 (2019) ("There exists a spectrum of interactions between the two sides [of a platform], with transactions simply being at one end of the spectrum, and 'mere' interactions of various sorts on the other. What matters for market definition is the nature of the externalities between the two sides and how the platform operator takes these externalities into account when setting prices.").

${ }^{140} \mathrm{Id}$.

141 See, e.g., Platinum Card, AM. EXPRESS, https://card.americanexpress.com/d/platinum-card/; Visa Consulting \& Analytics, VISA, https://usa.visa.com/partner-with-us/visa-consulting-analytics.html; Authentication Services, MASTERCARD, https:/www.mastercard.us/en-us/business/overview/safetyand-security/authentication-services.html.

142138 S. Ct. at 2287.
} 
compete with individual hotel websites and telephone calls, which are not platforms at all.

The error of this latter proposition soon became painfully obvious. In April 2020, Judge Stark of the District of Delaware rejected the DOJ's challenge to the acquisition of Farelogix by Sabre. ${ }^{143}$ Historically, airlines relied primarily on booking services provided by Sabre and two other global distribution systems ("GDS") to sell tickets to travel agents. ${ }^{144}$ Farelogix offered an alternative booking services solution that allowed airlines to bypass the GDSs and connect directly to travel agencies. ${ }^{145}$ Farelogix's products work with a new technology standard, New Distribution Capability, which allows airlines to make a broader, more personalized range of offers to travelers booking through travel agencies. ${ }^{146}$ Sabre had vigorously opposed this new technology in the market and in industry groups before changing tactics and agreeing to purchase Farelogix. ${ }^{147}$ DOJ sued to block the acquisition.

Judge Stark refused to enjoin the deal, holding that DOJ had failed to establish a prima facie case because it had failed to properly identify a relevant market. ${ }^{148}$ It was clear that the combination of Farelogix-plusairlines would allow airlines to disintermediate Sabre. Yet, citing Amex, the court held that, as a matter of law, Sabre (a two-sided transaction platform $)^{149}$ could only compete with other two-sided platforms. ${ }^{150}$ Farelogix only provides services to airlines and was, therefore, not a twosided platform. ${ }^{151}$ So, despite evidence that Sabre actually viewed Farelogix as a competitive threat through its relationship with airlines, the court determined that the two firms were not competitors. ${ }^{152}$ At trial, the DOJ attempted to limit Amex to the credit card industry, but Judge Stark did not

\footnotetext{
${ }^{143}$ United States v. Sabre Corp., 452 F. Supp. 3d 97 (D. Del. 2020).

${ }^{144} \mathrm{Id}$. at 110.

${ }^{145} \mathrm{Id}$. at 113 .

${ }^{146} \mathrm{Id}$. at 112 .

${ }^{147} \mathrm{Id}$. at 105 .

${ }^{148} I d$. at 136 .

149 The court was following the precedent established by the Second Circuit in US Airways, Inc. v. Sabre Holdings Corp., 938 F.3d 43.

150452 F. Supp. 3d at 136.

${ }^{151} I d$.

${ }^{152} \mathrm{Id}$. at 118 ("[A] preponderance of the evidence shows that Sabre and Farelogix do view each other as competitors, although only in a limited fashion. Sabre considers Farelogix a competitor in developing NDC technology for direct connects.").
} 
believe that the Amex opinion provided any rationale for such a limitation and maintained that he was bound by the precedent. ${ }^{153}$

As Sabre demonstrates, Amex has opened a door to the broader erosion of the substitutability principle, and that door may prove hard to shut. The path is now marked for lower courts to depart from substitutability for whichever reasons might seem persuasive to them. Today, many businesses and litigation defendants - in industries from ridesharing ${ }^{154}$ to collegiate athletics ${ }^{155}$ — are arguing that they should benefit from the "Amex exception." 156 As Erik Hovenkamp points out, there are "no potential defendants who would not benefit from this." "Some of those claims have been and will be accepted, and what was previously an antitrust axiommarkets are defined based on meaningful substitutes — will steadily erode. ${ }^{158}$

This is a harmful outcome. Legal certainty and analytical coherence will suffer; private and governmental plaintiffs will face more risk and will be deterred from bringing meritorious challenges, reducing deterrence; courts will face growing confusion; and businesses will find it harder to measure the legality of their planned conduct.

\section{B. Prescription: Balancing in Platform Cases}

These errors of Amex were needless. The Court could instead have acknowledged evidence of market power on one side, retained the substitutability-based approach to market definition, and avoided dubious economic distinctions, and it could have done so while recognizing the

\footnotetext{
${ }^{153} \mathrm{Id}$. at 137 . The DOJ is partly to blame for this outcome because it framed the merger as horizontal, rather than vertical or horizontal-plus-vertical. It was the relationship between Farelogix and the airlines that exerted competitive pressure on Sabre. Farelogix allowed the airlines to disintermediate Sabre and serve travel agencies directly. Analyzing this disintermediation as a vertical issue would have been much more sensible and may have avoided the issue of whether one-sided products can compete with two-sided platforms.

${ }^{154}$ See SC Innovations, Inc. v. Uber Techs., Case No. 18-cv-07440-JCS, 2020 WL 2097611 (N.D. Cal. May. 1, 2020).

${ }^{155}$ Alston, 594 U. S.

${ }^{156}$ See, e.g., Ted Tatos, Relevant Market Definition and Multi-Sided Platforms After Ohio v. American Express: Evidence from Recent NCAA Antitrust Litigation, J. SPORTS \& ENT. L. 147, 148-49 (2019).

${ }^{157}$ Erik Hovenkamp, Platform Antitrust, 44 J. Corp. L. 713, 752 (2019). Chris Sagers predicted this at the time of Amex itself. Chris Sagers, Ohio v. American Express: Clarence Thomas Sets Sail on a Sea of Doubt, and, Mirabile Dictu, It's Still a Bad Idea, ProMArket (June 27, 2018) ("[W]e can expect every antitrust defendant and their sister to start claiming that their business is two-sided, and lower courts will find reason within the theory to give their claims the time of day.").

${ }^{158}$ One of us has argued elsewhere that the substitutability principle could be reconciled with Amex only by splitting the market definition tool itself. See Francis \& Ezrielev, supra note 143, at 479.
} 
close economic relationship between the two sides of the American Express platform.

By insisting on a single market definition encompassing both sides, the Court was able to avoid making (or at least admitting to) this exception, and was able to place the burden on the plaintiff, rather than the defendant, to figure out whether the acknowledged harms were in fact offset by claimed benefits. ${ }^{159}$ The Court instead should have crafted a limited exception to the rule against multi-market balancing that is narrowly tailored and consistent with existing law, including the law of burdens of proof.

\section{The Traditional Rule Against Multi-Market Balancing}

Benefits in one market cannot normally be invoked to justify harms in another market. This rule certainly governs merger cases. ${ }^{160}$ And while the Supreme Court has not been entirely clear, there is a basis for thinking that it applies also in conduct cases. ${ }^{161}$ Justice Breyer acknowledged in dissent that "[a] Sherman Act $\S 1$ defendant can rarely, if ever, show that a procompetitive benefit in the market for one product offsets an anticompetitive harm in the market for another." 162 The District Court also nodded at the same difficulty. ${ }^{163}$

This principle implicates some important tensions in the design and application of antitrust rules. On the one hand, the rule prevents antitrust cases from becoming unwieldly, if not limitless, as they would be if every possible impact on every possible consumer group had to be measured or

159 Herbert Hovenkamp, Platforms and the Rule of Reason: The American Express Case, 2019 Columbia Bus. L. REV. 35, 60 (2019) ("What the . . majority was apparently trying to do is force the plaintiff to consider burdens and benefits on both sides of the platform as part of its prima facie case."). ${ }^{160}$ See Philadelphia Nat'l Bank, 374 U.S. at 371 ("[A] merger the effect of which 'may be substantially to lessen competition' is not saved because, on some ultimate reckoning of social or economic debits and credits, it may be deemed beneficial.").

161 Justice Breyer's dissent quoted from United States v. Topco Assocs., Inc., 405 U.S. 596 (1972). While the Topco Court was focused on the distinction between intrabrand and interbrand competition, Topco's antipathy to broad balancing is clear. See Topco, 405 U.S. at 610-12 (citing Philadelphia Nat'l Bank). Commentators differ regarding the existence and desirability of the rule for conduct cases. Compare Gregory J. Werden, Cross-Market Balancing of Competitive Effects: What Is the Law, and What Should It Be? 43 J. Comp. L. 119 (2017) with Jonathan B. Baker, ThE ANTITRUST PARAdigm (2019) 191.

162 See 138 S. Ct. at 2302-03 (Breyer, J., dissenting) (“American Express might face an uphill battle. A Sherman Act $\S 1$ defendant can rarely, if ever, show that a pro-competitive benefit in the market for one product offsets an anticompetitive harm in the market for another[.]").

16388 F. Supp. 3d. at 229 ("As a general matter, however, a restraint that causes anticompetitive harm in one market may not be justified by greater competition in a different market. Whether this rule precludes jointly weighing the relative gains and losses to Interbrand competition in two separate, yet interrelated, markets that together comprise a single two-sided platform has yet to be explicitly considered by the Second Circuit."). 
predicted before adjudication could take place. It is also consistent with formulations of the goal of antitrust as providing consumers in a relevant market with the benefit of competition for their business. ${ }^{164}$ Price discrimination markets underscore the antitrust policy of protecting injured consumer subgroups even if other consumers are unharmed or benefited by the challenged conduct. ${ }^{165}$

One the other hand, the rule directs a court to ignore effects on some consumers, which can lead the court to condemn conduct that is beneficial to consumers in some overall sense. ${ }^{166}$ Thus, it is in some tension with the central purpose of rule of reason analysis, which is to determine the overall competitive effects of challenged conduct. ${ }^{167}$ The rule also invites the criticism of formalism, to the extent that it treats effects in the relevant market dissimilarly from effects outside that market. Because market definition is not necessary in every case, and may rest on legal formalisms rather than economic realities, one might fairly be uneasy that this brightline distinction is doing so much heavy lifting. ${ }^{168}$

The question of whether and how to compare harms to some participants against benefits to others is not unique to multi-market platform cases. Consider retail price maintenance agreements ("RPM"), which can be justified when they make it possible to provide better services to consumers. ${ }^{169}$ In those cases, there can be conflicting effects within the single market. Suppose that only some of the consumers in the relevant market value the additional services, while all customers pay the resulting

164 See, e.g., Robert H. Lande, The Fundamental Goal of Antitrust: Protecting Consumers, Not Increasing Efficiency, 84 Notre Dame L. Rev. 191, 192 (2008) ("The fundamental goal of antitrust, in other words, is to protect consumers in the relevant market from anticompetitive behavior that exploits them - that unfairly transfers their wealth to firms with market power - not to increase the total wealth of society") (emphasis added); id. at 217 ("[T]he Court [has] signaled that the ultimate aim of antitrust law is to enhance the wellbeing of consumers in the relevant market[.]") (emphasis added).

165 See, e.g., R.R. Donnelley \& Sons Co., 120 F.T.C. 36 (1995).

${ }^{166}$ See, e.g., Eastman Kodak, 504 U.S. at 479 ("We need not decide whether Kodak's behavior has any procompetitive effects and, if so, whether they outweigh the anticompetitive effects. We note only that Kodak's service and parts policy is simply not one that appears always or almost always to enhance competition, and therefore to warrant a legal presumption without any evidence of its actual economic impact.").

167 See, e.g., 1-800 Contacts, Inc. v. FTC, No. 18-3848, 2021 WL 2385274, at *7 (2d Cir. June 11, 2021) (testing for "net procompetitive effect" under rule of reason); In re Sulfuric Acid Antitrust Litig., 703 F.3d 1004, 1011 (7th Cir. 2012) (focusing on "net effect on economic welfare"); Smith v. Pro Football, Inc., 593 F.2d 1173, 1186 (D.C. Cir. 1978) (rule of reason analysis involves identifying anticompetitive and procompetitive effects and "net[ting] them out").

168 See supra Section II.A.1. See also Michael Katz \& Jonathan Sallet, Multisided Platforms and Antitrust Enforcement, 127 YALE L.J. 2142, 2154 (2018) (“[O]ne should be very wary of putting too much weight on market definition itself as a driver of the key conclusions.").

169 See Leegin, 551 U.S. at 890-91 (noting that RPM agreements may stimulate interbrand competition). 
higher nominal price. RPM would thus benefit the consumers who value the services but would harm those who do not. ${ }^{170}$ This raises a fairness question: if there are only a few customers who value the services, should the RPM be considered beneficial overall ${ }^{171}$ And - crucially-should that conclusion change if we conclude instead that the two groups of customers represent two distinct relevant markets?

Commentators can and do differ about the right answer to these questions. ${ }^{172}$ The Horizontal Merger Guidelines provide support for reasonably circumscribed departures from the rule against multi-market balancing in the agencies' exercise of prosecutorial discretion when the benefits far exceed the harms. ${ }^{173}$

\section{Some First Principles for Platform Balancing}

In the context of multisided platforms, balancing harms and benefits on one side with harms and benefits on another side may be appropriate in certain, carefully prescribed and limited, circumstances. The Court's observation that effects on multiple sides of a platform business are often closely interconnected as a causal matter, and that antitrust analysis ought not

${ }^{170}$ Herbert Hovenkamp, Platforms and the Rule of Reason: The American Express Case, 2019 Columbia Bus. L. REV. 35, 45-46 (2019) (noting that antisteering rules deprive customers of the opportunity to choose between a lower-price, lower-benefit product and a higher-price, higher-benefit product, which - as consumers value perks differently-harms some). Compare, e.g., Christopher R. Leslie, Predatory Pricing and Recoupment, 113 Colum. L. Rev. 1695, 1720-32 (2013) (noting that the benefits of predatory pricing and the harms of recoupment may occur in different markets, thus affecting different consumer groups).

${ }^{171}$ It has been assumed by some commentators that the "overall" effect can be gauged by the effect on market output. If output increased, it was assumed that consumers are benefited overall, and harmed overall if market output falls. However, economists have known for decades that this assumption is incorrect if the value of services is not identical across all consumers. Under those circumstances, basing the comparison on the effects on total output is a defective approach. The benefits of the services to consumers "at the margin" may lead to an increase in output. But the harms to the inframarginal consumers may far more than exceed the benefits to the marginal consumers. See William Comanor, The Two Economics of Vertical Restraints, 5 REV. Indus. ORG. 99, 107 (1990); John M. Newman, The Output-Welfare Fallacy: A Modern Antitrust Paradox, 107 IowA L. REV. (forthcoming 2022). But see Herbert Hovenkamp, Antitrust Harm and Causation, Wash. U. L. Rev. (forthcoming 2021) ("There are good reasons for preferring output rather than price as the primary indicator of consumer welfare."). Measuring output is also fraught with other difficulties since the proper measure is "volume" in units, not revenue in dollars. Output also may increase or decrease secularly as demand changes over time, so it is necessary to "control" for these effects in order to properly measure the effect of the conduct.

${ }^{172}$ For a thoughtful overview, see Daniel A. Crane, Balancing Effects Across Markets, 80 Antitrust L.J. 391 (2015). See also Stephen F. Ross, The Misunderstood Alliance between Sports Fans, Players, and the Antitrust Laws, U. ILL. L. REV. 519, 540-541 (1997) (“[T]he Court's antitrust jurisprudence shows that quality-enhancing agreements are reasonable even if they make some parties worse off.").

${ }^{173}$ See, e.g., Horizontal Merger Guidelines $\S 10 \mathrm{n} .14$ ("Inextricably linked efficiencies are most likely to make a difference when they are great and the likely anticompetitive effect in the relevant market(s) is small so the merger is likely to benefit customers overall.") 
neglect this reality has some force. ${ }^{174}$ But the question of whether and when to compare effects should — consistent with the axioms of antitrust analysis - turn on economic substance, not on the formalism of market definition. For similar reasons, simply classifying a business as a platform should not set off a free-for-all. Instead, analysis should be structured and guided by the three principles described below.

We also acknowledge that the economic literature on two-sided markets has not reached consensus on the definition of a "platform." 175 As Katz and Sallet show, virtually any business can be shoehorned into some definition of a "platform." 176 For these purposes, we will accept the Supreme Court's definition of a platform as a business that "offers different products or services to two different groups who both depend on the platform to intermediate between them," "177 with the caveat that there may be more than two sides in some cases.

Instead of the Court's mangled approach of defining a single two-sided platform market, we propose that it makes more sense to balance crossplatform harms and benefits experienced by consumers on the two sides of the platform, defined as two separate markets, pursuant to the following principles. ${ }^{178}$ First, "other side" effects should be counted only if they are sufficiently causally connected to the challenged restraint. Second, a defendant must do more than just name a plausible justification: it must prove actual offsetting beneficial effects are of sufficient magnitude to

\footnotetext{
${ }^{174}$ See generally, e.g., Michael Katz, Exclusionary Conduct in Multi-Sided Markets, Note for OECD Hearing on Re-thinking The Use of Traditional Antitrust Enforcement Tools in Multi-Sided Markets (Nov. 15, 2017) (highlighting complexities in analysis of exclusionary conduct in markets with multisided businesses).

${ }^{175}$ See, e.g., Jean-Charles Rochet \& Jean Tirole, Two-Sided Markets: A Progress Report, 37 RAND J. ECON. 645-67 (2006). Rochet and Tirole defined a market as two-sided "if the platform can affect the volume of transactions by charging more to one side of the market and reducing the price paid by the other in an equal amount; in other words, the price structure matters, and platforms must design it so as to bring both sides on board." Evans and Schmalensee, by contrast, defined a two-sided market to be one that "has (a) two or more groups of customers; (b) who need each other in some way; (c) but who cannot capture the value from their mutual attraction on their own; and (d) rely on the catalyst to facilitate value creating interactions between them." David S. Evans and Richard Schmalensee, Markets with Two-Sided Platforms, in 1 IsSUES IN COMPETITION L. AND POL'Y 667 (2008).

${ }^{176}$ Katz \& Sallet, supra note 141, at 2149-51 ("Almost any firm selling an input to a manufacturer would prefer that the manufacturer have more customers, as then the manufacturer will demand more of the input."). Thus, someone might argue that virtually all firms (whether digital or brick-and-mortar) should be treated as platforms on the grounds that they buy inputs and sell products, a definition that would destroy usual market definition principles.

177138 S. Ct. at 2280.

178 The limitation to "other sides" of a single platform business helps, among other things, to avoid the analysis becoming unwieldy or unmanageable, or to avoid a court having to entertain arguments about so-called "butterfly effects." It does, however, include all effects in markets where the platform is active, including effects on those not literally purchasing from the platform.
} 
overcome the harms. And, third, when a court departs from the standard single-market rule to assess the benefits enjoyed on another side of the platform, it must also consider any other reasonably ascertainable effects of the challenged conduct, good and bad, on any side of the platform. On this approach, antitrust markets on each side of the platform would be defined according to traditional substitutability-based principles and could involve special analytical tools (like price-discrimination markets) in appropriate cases.

First, the requirement of causal connection between harms and benefits is a crucial limiting factor. Courts should not entertain arguments about benefits that would be provided absent the restraint or through significantly less restrictive means. ${ }^{179}$ In drawing a line, courts should heed guidance in the agencies' 2010 Horizontal Merger Guidelines, which acknowledges that, as a matter of prosecutorial discretion, the agencies will consider out-ofmarket benefits in a merger review only if those benefits are "inextricably linked" with the harms, such that they would be lost if the harmful effect were prohibited. ${ }^{180}$

Limiting balancing to causally connected effects-considering only benefits that a defendant proves would not be achieved if the restraint were prohibited - makes both economic and legal sense. If a claimed benefit could be achieved without a restraint that causes consumer harm, then there is no need to tolerate the consumer harm to achieve the consumer benefit. ${ }^{181}$ This approach also serves the ultimate goal of the rule of reason-to assess the overall effect of a challenged restraint — and fits existing guidance and enforcement practices in merger enforcement. ${ }^{182}$ The 2010 Horizontal Merger Guidelines also explain the agencies will consider out-of-market benefits in a merger review only if those benefits would be substantial relative to harms. ${ }^{183}$

Second, regarding the allocation of burdens of proof within the rule of reason framework, generally plaintiffs should have the burden of showing

179 Alston, 594 U.S. at _ (slip op. at 28) ("[H]owever framed and at whichever step, anticompetitive restraints of trade may wind up flunking the rule of reason to the extent the evidence shows that substantially less restrictive means exist to achieve any proven procompetitive benefits.") (citing 7 Phillip E. Areeda \& Herbert Hovenkamp, Antitrust Law 1 1505, p. 428 (4th ed. 2017)).

${ }^{180}$ Horizontal Merger Guidelines $§ 10 \mathrm{n} .14$ (emphasis added).

181 The Horizontal Merger Guidelines require the existence of "merger-specific efficiencies." See Horizontal Merger Guidelines $\S 10$ ("The Agencies credit only those efficiencies likely to be accomplished with the proposed merger and unlikely to be accomplished in the absence of either the proposed merger or another means having comparable anticompetitive effects.").

$182 \mathrm{Id}$; see also Francis \& Ezrielev, supra note 143, at 480-85 (emphasizing the benefits of causationbased limits for effects analysis in platform cases).

${ }^{183} \mathrm{Id}$. 
harms and defendants should have the burden of showing benefits. To satisfy the burden of showing redeeming beneficial effects, a defendant should not be able to simply invoke the specter of procompetitive benefits. It also must demonstrate that such benefits exist and are of sufficient magnitude to overcome the harms proven by the plaintiff. It must also be reasonably possible for the court to evaluate and weigh the evidence provided by each party. ${ }^{184}$

The Supreme Court's approach in Amex defied this allocation principle. Because of its contorted market definition, the Court effectively required plaintiffs to not only prove anticompetitive harm but also to disprove any plausible procompetitive benefit in order to satisfy its prima facie case. ${ }^{185}$ This is backwards. The defendant has much better access to evidence of benefits; forcing a plaintiff to disprove the sufficiency of every possibly invoked justification would undesirably redouble an already forbidding evidentiary burden. ${ }^{186}$ Finally, maintaining this burden on the defendant is consistent with the longstanding approach under the rule of reason that the defendant prove that benefits in the same market side offset apparent harms in that market. ${ }^{187}$ Claims of benefit should not be analyzed more favorably simply because they fall on a different side of the platform.

Third, when analyzing cross-platform effects, both benefits and harms on all sides of the platform should be counted. Suppose that the plaintiff alleges harms from the restraint suffered by consumers in a market on one side of the platform and the defendant asks a court to consider a benefit enjoyed by a particular customer group on the other side of the platform. In this case, the court should also consider effects on other consumer groups on other sides of the platform reasonably connected to the challenged conduct. Burdens of proof regarding these effects should follow the

\footnotetext{
184 See Andrew I. Gavil \& Steven C. Salop, Probability, Presumptions and Evidentiary Burdens in Antitrust Analysis: Revitalizing the Rule of Reason for Exclusionary Conduct, 168 U. PENN. L. REV. 2107 (2020). Courts do not always demonstrate adequate concern for the magnitude of the benefit offered by the defendant at step two. See, e.g., Capital Imaging v. Mohawk Valley Med. Assoc, 996 F.2d 537, 543 (2d Cir. 1993) (stating that the defendant, once the burden shifts to them, must "offer evidence of the pro-competitive "redeeming virtues' of their combination," and that "[a]ssuming defendant comes forward with such proof," the plaintiff once again assumes the burden of production"). For a thoughtful overview, see generally John M. Newman, Procompetitive Justifications in Antitrust Law, 94 IND. L.J. 501 (2019).

$185138 \mathrm{~S}$. Ct. at 2288.

186 See Herbert Hovenkamp, Platforms and the Rule of Reason: The American Express Case, 2019 Columbia Bus. L. REV. 35, 57 (2019) (noting that a defendant "is in a far better position" to provide such evidence). See also Elkins v. United States, 364 U.S. 206, 218 (1960) ("[A]s a practical matter, it is never easy to prove a negative.").

187 4A Phillip E. Areeda \& Herbert HovenKamp, ANTitrust Law 1040 (4th ed. 2016).
} 
ordinary rules: benefits are for the defendant to prove, and harms are for the plaintiff.

This symmetry rule will not affect the outcome in every case. ${ }^{188}$ But in many cases, it will matter: a restraint may simultaneously harm some participants, and benefit others, on each side of the platform. As discussed in Part III, this seems to have been exactly the impact in Amex itself: some consumers (namely, some American Express cardholders) were benefited, but other cardholders were also harmed. ${ }^{189}$

\section{Allocating Burdens Correctly}

Effects balancing is often described as the third step of the rule of reason, but we think it is best integrated into the second stage of rule-of-reason analysis. ${ }^{190}$ To discharge its burden at this stage, the defendant should be required to show not only that the procompetitive justification is applicable, valid and non-pretextual, but also that it is sufficient in magnitude to offset the competitive harms. ${ }^{191}$ This approach avoids the false negative errors that can result if a defendant must only identify a qualitative benefit to its own business before a plaintiff is required to quantify that benefit and set it off against overall harms. ${ }^{192}$

The quantum of evidence that should be required for a defendant to discharge this burden also is a function of the plaintiff's own evidentiary showing. A feather of justification evidence should not be sufficient to trump a pound of evidence of harm. ${ }^{193}$ However, if the plaintiff has

\footnotetext{
${ }^{188}$ For example, suppose that small marketplace platform requires vendors to use its lower cost logistics system while charging a supracompetitve fee, which is found to lead to lower merchandise prices, and these lower prices are matched by the larger platforms.

189138 S. Ct. at 2288.

${ }^{190}$ See, e.g., U.S. v. Visa U.S.A., Inc., 163 F. Supp. $2 \mathrm{~d} 322$.

${ }^{191}$ See, e.g., United States v. Brown Univ., 5 F.3d 658, 678 (3d Cir. 1993) ("[T]he district court was obliged to more fully investigate the procompetitive and noneconomic justifications proffered by MIT than it did when it performed the truncated rule of reason analysis."). Of course, in practice many courts have required much less of defendants. See, e.g., United States v. Microsoft Corp., 253 F.3d 34, 59 (D.C. Cir. 2001) (explaining that "the monopolist may proffer a 'procompetitive justification' for its conduct. .. If the monopolist asserts a procompetitive justification - a nonpretextual claim that its conduct is indeed a form of competition on the merits because it involves, for example, greater efficiency or enhanced consumer appeal - then the burden shifts back to the plaintiff to rebut that claim") (emphasis added).

192 Cf. Gavil \& Salop, supra note 193; see also Daniel Francis, Making Sense of Monopolization, 84 ANTITRUST L.J. (forthcoming 2022).

193 This issue touches an important controversy in the law of evidence regarding the structure of a showing required to rebut a presumption. See generally Ernest F. Roberts, An Introduction to the Study of Presumptions, 4 VILL. L. REV. 1, 15-21 (1958) (comparing Thayerian view, pursuant to which a presumption has no further operation after the introduction of evidence tending to rebut it, with its
} 
discharged its own burden through mere identification, circumstantial evidence, tenuous inferences, or recourse to a formalistic legal presumption, the defendant's obligation should be proportionately lessened.

This is broadly consistent with the approach in merger cases. In cases where the plaintiff provides evidence of anticompetitive harms, courts tend to scrutinize purported justifications with skepticism and caution. ${ }^{194}$ For example, the D.C. Circuit in Baker Hughes on the one hand emphasized that defendants should not be forced to rebut a "probability with a certainty,"195 while on the other hand requiring the production of actual evidence of efficiency benefits, not merely the identification of possible benefits. ${ }^{196}$ Consistent with our approach, the court adopted a sliding scale, noting that " $[\mathrm{t}]$ he more compelling the prima facie case, the more evidence the defendant must present to rebut it successfully." 197 This production burden, of course, does not change the plaintiff's ultimate burden of persuading the court that a violation of law has occurred.

Thus, we disagree with the language the D.C. Circuit used in Microsoft when it superficially appeared to suggest that if a defendant monopolist merely "asserts" a non-pretextual procompetitive justification, that should be sufficient to shift a burden back to the plaintiff. ${ }^{198}$ If taken literally — as, surely, the Microsoft court did not intend - that approach would force the plaintiff to prove a negative by disproving the possibility that the asserted benefit may be sufficient in magnitude to offset the harms and thereby artificially raise the plaintiff's burden of proof. 199 "Assertion" does not require evidence. But that literal interpretation should be rejected: it is unreasonable and inefficient to force the plaintiff to shoulder the burden of elaborating and quantifying a defense based on an improvement in the

leading alternative - today sometimes known as the Morgan-McCormick view-which imposes a burden of persuasion on the rebutting party). See also Steven C. Salop, An Enquiry Meet for the Case: Decision Theory, Presumptions, and Evidentiary Burdens in in Formulating Antitrust Legal Standards 33-34 (Nov. 6, 2017) (unpublished manuscript) (on file with author at https://scholarship.law.georgetown.edu/facpub/2007/).

194 See, e.g., United States v. Anthem, Inc., 855 F.3d 345 (D.C. Cir. 2017) (scrutinizing closely defendants' proffered efficiencies); FTC v. Staples, Inc., 970 F. Supp. 1066, 1089-1090 (D.D.C. 1997) (same).

${ }^{195}$ See United States v. Baker Hughes Inc., 908 F.2d 981, 992 (D.C. Cir. 1990).

${ }^{196}$ Id. ("The burden of producing evidence to rebut this presumption then shifts to the defendant.") (emphasis added).

${ }^{197}$ Id. at 991. See also, e.g., FTC v. CCC Holdings Inc., 605 F.Supp.2d 26, $46-47$ (D.D.C. 2009).

198 United States v. Microsoft Corp., 253 F.3d 34, 59 (D.C. Cir. 2001). See also Francis, supra note 201.

199 The court's own analysis of the code-commingling allegation suggests a more meaningful evidentiary burden on the defendant. See Microsoft, 253 F.3d at 66-67 (noting that Microsoft "neither specifies nor substantiates" claimed benefits from commingling of Internet Explorer's code with Windows). 
efficiency of the defendant's business. Plaintiffs invariably have less access to the relevant information, so such a rule also violates principles of efficient decision-rule design. ${ }^{200}$

If the defendant satisfies its burden of showing that the benefits of conduct outweigh the harms, then the burden shifts back to the plaintiff to rebut the defendant's conclusion or prove that a significantly less restrictive alternative is available, as explained in Alston. ${ }^{201}$

\section{The Ultimate Rule of Decision}

In accordance with these conditions - causal connection, correct allocation of the burdens of proof, and symmetry - relaxing the general rule against multi-market balancing can be a principled and helpful approach in an appropriate set of platform cases. ${ }^{202}$

This still leaves the fundamental question of how to aggregate and weigh these effects. Courts and agencies have several options, reflecting different approaches to relative harms, benefits, and costs (including error costs), ${ }^{203}$ whether in platform cases or in other cases involving harms to some consumers and benefits to others:

(1) a pure Pareto-based "no consumer harmed" standard that would not permit harm to any individual consumer;

(2) a "no group harmed" standard that would not permit net-harm to any well defined groups of consumers;

\footnotetext{
${ }^{200}$ This also applies in the context of Section 2, see Francis, supra note 201. Andrew I. Gavil \& Steven C. Salop, Probability, Presumptions and Evidentiary Burdens in Antitrust Analysis: Revitalizing the Rule of Reason for Exclusionary Conduct, 168 U. PENN. L. ReV. 2107 (2020)1; Bruce L. Hay \& Kathryn E. Spier, Burdens of Proof in Civil Litigation: An Economic Perspective, 26 J. Legal STUD. 413 (1997); C. Frederick Beckner III \& Steven C. Salop, Decision Theory and Antitrust Rules, 67 AnTITRUST L.J. 41-76 (1999).

${ }^{201}$ Alston, 594 U.S. _ (slip op. at 24-25). See also Viamedia, Inc. v. Comcast Corp., 951 F.3d 429, 488 (7th Cir. 2020) (citing Microsoft for the proposition that a defendant bears the burden of "proving procompetitive justification"); New York v. Actavis, PLC, Case No. 14-Civ-7473, 2014 WL 7015198 (S.D.N.Y. Dec. 11, 2014) (citing Microsoft for the proposition that "the procompetitive benefits of the business justification must outweigh the anticompetitive effects").

${ }^{202}$ We note the question - beyond the scope of this article — of whether and when this balancing rule should be applied outside of the platform context. We also acknowledge that applying special rules to a subset of cases will affect parties' incentives to attempt to plead into or out of that subset. (This is, of course, a consequence of Amex itself.)

${ }^{203}$ For an overview of the application of decision theory to antitrust rules, see Steven C. Salop, An Enquiry Meet for the Case: Decision Theory, Presumptions, and Evidentiary Burdens in in Formulating Antitrust Legal Standards 33-34 (Nov. 6, 2017) (unpublished manuscript) (on file with author at https://scholarship.law.georgetown.edu/facpub/2007/). See also Andrew I. Gavil \& Steven C. Salop, Probability, Presumptions and Evidentiary Burdens in Antitrust Analysis: Revitalizing the Rule of Reason for Exclusionary Conduct, 168 U. PENN. L. REV. 2107 (2020); see generally Isaac Erlich \& Richard A. Posner, An Economic Analysis of Legal Rulemaking, 3 J. Legal Stud. 257 (1974).
} 
(3) a "no side harmed" approach that would condemn a practice or transaction whenever it was net-harmful to consumers on any one side of a platform, even if there were greater benefits to consumers on other sides;

(4) a "neutral weighing" approach that would allow harm to some consumers to be justified by redeeming benefits to others, if the benefits were sufficient in magnitude to fully offset the harms (i.e., without weighting);

(5) a "harm-weighted" standard that gives greater weight to the interests of consumers who are harmed overall and thus requires a more compelling showing of offsetting benefits; and

(6) a "benefit-weighted" standard that gives greater weight to the interests of consumers who are benefited overall, and thus requires a more compelling showing of offsetting harms.

There is more to say about these options than there is space here and we acknowledge the need for further work on the normative and technical aspects of antitrust balancing. ${ }^{204}$ Option 1 would effectively prohibit virtually any conduct within the scope of the rule, reflecting the wellknown impracticality of the Pareto criterion in the real world. ${ }^{205}$ Option 2 shares much DNA with antitrust's traditional price-discrimination market approach, and it is likely to condemn most restraints in platform environments. ${ }^{206}$ Option 3 resembles the traditional, separate-markets approach in Philadelphia National Bank that entirely rejects crossplatform balancing. ${ }^{207}$ Option 4 offers the promise of keeping platform antitrust focused on overall effects in affected markets, albeit at the cost of tolerating harm to individual consumer groups.

Options 5 and 6 place "thumbs on the scale" in favor of consumers harmed or benefited respectively. Option 5 weights more highly those consumers who are harmed by the restraint, effectively prioritizing their protection from economic harm over access to economic benefits by others. ${ }^{208}$ Option 6 reflects an analogous anti-intervention view. ${ }^{209}$ Note that, at least in

\footnotetext{
${ }^{204}$ For one very helpful contribution, see, e.g., Rebecca Haw Allensworth, The Commensurability Myth in Antitrust, 69 VAND. L. REV. 1 (2016).

${ }^{205}$ Herbert HovenKamp, Federal Antitrust Policy $§ 2.3 \mathrm{c}$ (6th ed. 2020).

${ }^{206}$ See Horizontal Merger Guidelines $\S 3$.

${ }^{207}$ Katz \& Sallet, supra note 141, at 2158; see also Philadelphia Nat'l Bank, 374 U.S. at 363.

${ }^{208}$ Compare Horizontal Merger Guidelines $§ 10 \mathrm{n} .14$ ("Inextricably linked efficiencies are most likely to make a difference when they are great and the likely anticompetitive effect in the relevant market(s) is small so the merger is likely to benefit customers overall."). In principle, a protected group might be based on grounds such as income level or other vulnerability. Cf. Jonathan B. Baker \& Steven C. Salop, Antitrust, Competition Policy, and Inequality, 104 GEO. L.J. 1, 24-26 (2015). This might be justified, for example, by reference to the diminishing marginal utility of wealth. See generally, e.g., Daniel Crane, Antitrust and Wealth Inequality, 101 Cornell L. Rev. 1171 (2016).

${ }^{209}$ See, e.g., Frank H. Easterbrook, The Limits of Antitrust, 63 TEX. L. REV. 1 (1984).
} 
principle, there are at least two obvious ways in which one could place such a thumb on the scale: the first would be to apply a "discount rate" to the magnitude of one or other type of effect while conducting the balancing; the second would be to require more cogent proof of one or other type of effect before it can be held cognizable.

Even these options likely do not exhaust the possibilities. There may not be consensus about the "correct" balancing standard. But the need to choose one is inescapable, and that choice should be made openly rather than hiding the ball, as the Amex Court did.

\section{APPLying THE FramewORK: AMEX AS IT SHOUld HAVE BEEN}

In Part II, we examined the Amex Court's central errors of principle and we set out a framework for the appraisal of rule-of-reason cases in platform markets. In this Part, we apply that framework to the record in Amex itself. Our analysis is structured to conform with familiar rule of reason burden shifting. First, we consider the theoretical and evidentiary basis of harm to competition in Amex. Next, we consider American Express's evidence of procompetitive justification, applying our proposed "platform exception" to the general rule against multi-market balancing. Finally, we consider how the ledger of effects might have been compared and balanced, showing that on almost any plausible view - including most of the metrics discussed in Part II-the record compelled a finding for the plaintiffs.

\section{A. Harm to Competition}

In the first stage of rule-of-reason analysis, a plaintiff must provide direct or indirect prima facie evidence of a substantial anticompetitive effect. ${ }^{210} \mathrm{In}$ practice, the vast majority of litigated Section 1 civil antitrust suits fail at this stage. ${ }^{211}$ As a result, the case law is particularly well developed on the methods a plaintiff may use to show harm to competition, including adverse impacts on price, output, quality, innovation, and other indicia of competition. $^{212}$

\footnotetext{
${ }^{210}$ See Alston, 594 U.S. at _(slip op. at 24-25).

${ }^{211}$ Michael Carrier has calculated that between 1999 and 2009, "[c]ourts dispose[d] of 97\% of cases at the first stage, on the grounds that there is no anticompetitive effect," and "balance[d] in only $2 \%$ of cases." Michael A. Carrier, The Rule of Reason: An Empirical Update for the $21^{\text {st }}$ Century, 16 GEO. MASOn L. ReV. 827, 828 (2009); see also Michael A. Carrier, The Real Rule of Reason: Bridging the Disconnect, 1999 BYU L. REV. 1265 (1999).

212 This is consistent with the kind of evidence that has successfully discharged the plaintiff's burden in rule-of-reason cases in other industries. In NCAA v. Board of Regents, for example, the Supreme
} 
The Amex record contained plentiful evidence of anticompetitive effects. In particular, the plaintiffs had shown that:

- American Express had "repeatedly and profitably raised its [merchant fees] to millions of merchants across the United States ... without losing a single large merchant and losing relatively few small merchants as a result"; 213

- the antisteering rules had created or contributed to a pricing umbrella, allowing Visa and MasterCard to raise their own fees with "virtual impunity"; 214

- in addition to effects on merchants, these merchant fee increases "were not paired with offsetting adjustments on the cardholder side of the platform," and as such were "properly viewed as changes to the net price charged across Amex's integrated platform", ${ }^{215}$ and

- all consumers-including American Express cardholders and other cardholders, and non-cardholders who purchased from merchants who accepted credit cards - paid higher merchandise prices as a result of the rules, regardless of whether they were receiving card benefits. ${ }^{216}$

Under the approach we outlined in Part II, it would have been sufficient for the plaintiffs to have furnished evidence of harm in a single market on one side of the platform, such as the market for credit card services to merchants. In this analysis, the merchants are the direct participants on their

Court held that a plaintiff had satisfied its initial burden by showing both limitations of output, in the form of a ceiling on the number of televised sports games, and price increases arising from a loss of price competition among member schools. Board of Regents, 468 U.S. at 113. Likewise, in Realcomp II, Ltd. v. FTC, 635 F.3d 815 (6th Cir. 2011), the Sixth Circuit affirmed a finding that a restraint had suppressed competition for certain real estate services, based on a record that included evidence that the restraint was correlated with a statistically significant decrease in a low-cost form of competition. See Realcomp II, 635 F.3d 833-34. In Graphics Products Distributors v. Itek Corp., 717 F.2d 1560 (11th Cir. 1983), the Eleventh Circuit found that the challenged restraints had eliminated competition and that they threatened "substantially adverse effects on price competition and consumer welfare," based on testimony that the excluded competition would have been qualitatively significant and evidence of a substantial price increase as a result of the restrictions. Itek, 717 F.2d at 1575 . In L.A. Memorial Coliseum v. Nat'l Football League, 726 F.2d 1381 (9th Cir. 1984), the Ninth Circuit held that competitive harms were "plain" when the challenged restrictions insulated [NFL] teams from competition and "allow[ed] them to set monopoly prices to the detriment of the consuming public." L.A. Memorial Coliseum, 726 F.2d at 1395. In Roseborough Monument Co. v. Memorial Park Cemetery, 666 F.2d 1130 (8th Cir. 1981), the Eighth Circuit held that anticompetitive effects were "obvious" from a horizontal arrangement among cemeteries that reserved foundation preparation services at each cemetery to the cemetery itself, excluding other cemeteries and independent operators from competing for the work, even when they could perform "the same . . . service at a lower price." 666 F.2d at $1139-40$.

${ }^{213} \mathrm{Id}$. at 195 .

${ }^{214} \mathrm{Id}$. at 202; see also id. at 216 ("Visa and MasterCard, for instance, were able to increase their average all-in merchant rates through a variety of means by more than $20 \%$ from 1997 to 2009 , without fear of other networks undercutting their prices in order to gain share.").

${ }^{215} I d$. at 196.

${ }^{216} I d$. at 150; see also id. at 208. 
side of the platform and are considered consumers in the relevant sense: the effects on their welfare includes the effects passed on to consumers who do not pay with credit cards.

The evidence in the record also supported overall harm, not just harm to merchants. Merchants, most cardholders, and non-cardholding consumers were all harmed by the restraints, at least before considering any separate potential benefits like a "credentialing" or "welcome acceptance" effect. ${ }^{217}$ As Justice Breyer's dissent correctly noted, the District Court's factual findings on these net effects - particularly the finding that harms to merchants were not in fact offset by effects on cardholders - were "unchallenged." 218

This direct evidence of anticompetitive effects was buttressed by the nature of the restraint. An antisteering rule amounts to a "retail price most favored nation" agreement ("MFN"): that is, an agreement that prohibits a retailer from treating other suppliers more favorably than it treats the supplier imposing the rule. ${ }^{219}$ Economic theory teaches that such agreements can have the effect of softening interbrand price competition at the point of sale and of encouraging competitors to increase or maintain their own fees, rather than reduce them. ${ }^{220}$ Indeed, a central effect of the American Express rule here was to ensure that a reduction in Visa's or Mastercard's fees would not result in merchant steering away from American Express to Visa or Mastercard, thereby eroding the incentive for those other cards to compete aggressively with American Express on price. ${ }^{221}$ In addition, American Express furnished no reason to expect competitive benefits often claimed for MFNs, such as transaction cost savings from negotiating price discounts. 22

\footnotetext{
${ }^{217}$ See 88 F. Supp. 3d at 216-17 (discussing "the cost of the premium rewards conferred by American Express on its relatively small, affluent cardholder base in the form of higher retail prices").

218138 S. Ct. at 2301-02 (Breyer, J., dissenting).

${ }^{219}$ This interbrand restraint was similar to the restraint that was condemned in the Apple e-books case. See United States v. Apple Inc., 952 F. Supp. 2d 638 (S.D.N.Y. 2013).

${ }^{220}$ Dennis W. Carlton \& Ralph A. Winter, Vertical MFN's and the Credit Card No-Surcharge Rule, 61 J.L. \& ECon. 215 (2018); Jonathan B. Baker \& Fiona Scott Morton, Antitrust Enforcement Against Platform MFNs, 127 YALE L. J. (2018).

221 The District Court made this finding. However, the Supreme Court, without overruling the District Court's finding and without any support for its assertion, insisted that Visa and MasterCard retained incentives to compete on price in the face of the restraints. $138 \mathrm{~S}$. Ct. at 2290 (stating that "antisteering provisions do not prevent Visa, MasterCard, or Discover from competing against Amex by offering lower merchant fees or promoting their broader merchant acceptance").

22211 Phillip E. Areeda \& Herbert Hovenkamp, Antitrust Law 11807 (4th ed. 2018). An analogous intrabrand MFN would involve a contractual promise by Amex to charge the same merchant fee to all retailers.
} 


\section{The Neglected Parallelism of Antisteering}

Neither the various courts in the Amex litigation, nor the plaintiffs, focused on an important dimension of the economics of antisteering: the interactions between the effects of American Express's antisteering rules and effects of the parallel antisteering rules of Visa and MasterCard. ${ }^{223}$ The Court ignored the fact that, during most of the period under analysis, all three networks had antisteering rules. In addition, the Court did not appear to consider that American Express's rule also contributed to Visa's and Mastercard's ability and incentives to increase their own fees during this period and prevented competitive strategies based on low merchant fees. ${ }^{224}$

Although American Express was the lone defendant at trial, and despite careful emphasis in the complaint that each rule alone was anticompetitive, ${ }^{225}$ both theory and evidence suggest the effects of the antisteering restrictions implemented earlier by American Express, Visa, and Mastercard were mutually reinforcing. ${ }^{226}$ That is, each company had a better ability and incentive to set supracompetitive fees because the other two major credit cards also imposed antisteering rules during the relevant period.

The economic analysis is straightforward. Visa's antisteering rule eliminated the incentive of MasterCard and American Express to cut their merchant fees but did not eliminate Visa's incentive to do so. However, the American Express antisteering rule perfected the anticompetitive effect by eliminating Visa's and MasterCard's incentives to cut their fees. At the same time, each of the rules increased the unilateral incentive of the network imposing it to raise its fees, because it gives the network confidence that the merchant would be unable to steer consumers to the

\footnotetext{
${ }^{223}$ In its recent decision affirming dismissal of damages claims against American Express by a class of non-Amex accepting merchants, the Second Circuit pointed to "uncertainty of how eliminating Amex's Anti-Steering Rules would affect its competitors' merchant fees," while nevertheless acknowledging that the District Court found Amex's antisteering rules "enabled Visa and MasterCard to 'increase their average all-in merchant rates . . . by more than $20 \%$. . . without fear of other networks undercutting their prices in order to gain [market] share,"” and the Supreme Court "did not question this finding." Opinion at 19 n.8, In re American Express Anti-Steering Rules Antitrust Litigation, No. 20-1766 (Nov. 22, 2021).

22488 F. Supp. 3d. at 201-02; see also Discover Brief Amicus Curiae, *7.

${ }_{225}$ Amended Complaint for Equitable Relief at 9 23, United States v. Am. Express Co., No. CV-104496 (NGG)(RER) (E.D.N.Y. Dec. 21, 2010) (“Each Defendant's set of vertically imposed restrictions independently restrains competition among networks. Each Defendant's Merchant Restraints violate Section 1 of the Sherman Act apart from the existence of the other two Defendants' Merchant Restrictions.").

${ }^{226}$ For a general discussion of the consequences of parallel vertical restraints, see generally C. Scott Hemphill \& Tim Wu, Parallel Exclusion, 122 Yale L.J. 1182 (2013).
} 
other networks. ${ }^{227}$ Yet, while the Court said, "the cause of increased merchant fees is not Amex's antisteering provisions, but rather increased competition for cardholders," 228 the Court ignored the obvious role of antisteering rules in driving fees up and keeping them high. In this regard, the Court also ignored evidence suggesting that the antisteering rules were the cause of the failure of Discover's competitive strategy of offering lower merchant fees. ${ }^{229}$

As in many cases involving vertical restraints in an oligopolistic market, the compounding effects of parallel restraints are intuitively plausible and a ground for increased competitive concern. Indeed, the Leegin Court acknowledged that even intrabrand vertical restraints "should be subject to more careful scrutiny . . . if many competing manufacturers adopt the practice. ${ }^{230}$ Moreover, the credit card market was highly concentrated. Calculating shares based on the dollar value of transactions, American Express's market share was $26 \%$ in this highly concentrated market, where Visa had a 47\% share and MasterCard had a 23\% share. ${ }^{231}$ Accordingly, the market was prone to oligopoly effects, and American Express's retail interbrand MFN was well placed to lead or support parallel practices by the other two oligopolists.

To be clear, we do not suggest that there was an express agreement among the three credit card networks to institute or maintain antisteering rules. If there had been evidence of such naked collusion, per se illegality would have been the likely result. ${ }^{232}$ Nor do we suggest that consciously parallel conduct is unlawful. ${ }^{233}$ Rather, our point is that the contribution of the antisteering rule to price increases by its competitors should have been reflected in the Court's analysis of the effects of that rule. It is a truism of rule of reason case law that the effects of restrictive practices must be assessed in light of their distinctive circumstances. ${ }^{234}$ When a restrictive

\footnotetext{
${ }^{227}$ This impact is subject to the ability of consumers to switch to non-credit card alternatives, such as cash or debit cards. However, both the credit facility and convenience drive consumer preference for credit card usage.

228138 S. Ct. at 2288.

${ }^{229}$ Discover Brief Amicus Curiae at *8.

${ }^{230}$ Leegin, 551 U.S. at 898.

23188 F. Supp. 3d at 188.

${ }^{232}$ In fact, when Visa and Mastercard adopted their no-surcharge rules and other rules requiring all issuers to be treated the same, the two networks had a governance scheme that permitted member banks to "have formal decision-making authority in one system while issuing a significant percentage of its credit and charge cards on a rival system." Visa U, 163 F. Supp. 2d at 328 (internal quotations omitted). ${ }^{233}$ See Theatre Enterprises v. Paramount Distributing, 346 U.S. 537, 541 (1954).

234 See Alston, 594 U.S. at (slip op. at 16) (describing rule-of-reason analysis as a "fact-specific assessment of market power and market structure aimed at assessing the challenged restraint's actual effect on competition - especially its capacity to reduce output and increase price") (internal quotation marks and citations omitted).
} 
practice significantly increases the ability and incentive of other competing firms to raise prices or to impose or maintain similar restraints, such competitor responses should be included in the assessment of competitive effects. ${ }^{235}$

The Court appeared entirely blind to this concern, and even misinterpreted fee increases by Visa and Mastercard as evidence in American Express's favor:
In addition, the evidence that does exist cuts against the plaintiffs' view that Amex's antisteering provisions are the cause of any increases in merchant fees. Visa and MasterCard's merchant fees have continued to increase, even at merchant locations where Amex is not accepted and, thus, Amex's antisteering provisions do not apply.... This suggests that the cause of increased merchant fees is not Amex's antisteering provisions, but rather increased competition for cardholders and a corresponding marketwide adjustment in the relative price charged to merchants. ${ }^{236}$

The relevant passage is remarkable in its lack of attention to the pernicious tendency of parallel antisteering rules. As we explain next, the Court's focus on output over price effects further demonstrates its misunderstanding of the compounding anticompetitive effects of American Express' antisteering rules.

\section{The Prisoner's Dilemma and Its Effect on Output}

If consumers were harmed by the antisteering rules, as the District Court concluded, why didn't the consumers choose to pay with debit cards, cash or checks?

One explanation is that the credit card antisteering rules contributed to a collective action problem among consumers, amounting to a Prisoner's Dilemma. The causal sequence is as follows: first, by charging a higher merchant fee, a credit card network can provide greater rewards to card users; second, the higher merchant fee combined with the antisteering rule causes merchants to raise merchandise prices across the board, rather than

\footnotetext{
235 See U.S. Gypsum Co. v. Indiana Gas Co., Inc. 350 F.3d 623, 627 (7th Cir. 2003) ("[A] cartel cuts output, which elevates price throughout the market; customers of fringe firms (sellers that have not joined the cartel) pay this higher price, and thus suffer antitrust injury, just like customers of the cartel members.").

236138 S. Ct. at 2288 (emphasis added) (citations omitted). Despite the 2010 Visa and Mastercard consent decrees, the American Express antisteering rules prevented them from steering at stores where American Express was accepted. Their normal uniform policies would have made it difficult for the merchant to engage in steering policies only at the minority of predominately small stores where American Express was not accepted.
} 
surcharging transactions made with the higher fee card; third, as a result, each individual consumer has a greater incentive to use credit cards more intensively to benefit from its rewards - increasing the fee burden on merchants still further and driving the cycle again; fourth, as more consumers use credit cards, merchandise prices paid by all consumers are increased further.

This is a classic Prisoner's Dilemma, that is, a situation in which each participant's unilateral pursuit of its own best interests leads to an outcome that is worse overall for all the participants. From the individual consumer's perspective, the benefit of the rewards offsets the harm from the de minimis marginal increase in merchandise prices caused by that single individual's decision to use the card, so it is individually rational to use the card. Other consumers do the same, forcing merchandise prices further upward. Since merchandise prices are going to be elevated anyway, it is better to enjoy rewards than not to do so. However, like other Prisoner's Dilemmas, the mere fact that an individually rational consumer would choose to use a card in a world of antisteering does not mean that cardholding consumers collectively would be better off from doing so than they would be absent the restraint. ${ }^{237}$ In fact, most consumers may be collectively worse off from the increased card usage. ${ }^{238}$

Of course, the real world is more complicated. The wealthiest consumers who obtain the largest rewards may benefit on balance from rewards that exceed the increase in merchandise prices. Others who receive smaller rewards or consumers who do not use credit cards-likely less wealthy

\footnotetext{
${ }^{237}$ See also John M. Newman, The Output-Welfare Fallacy: A Modern Antitrust Paradox, 107 IowA L. REV. (forthcoming 2022) (noting the dilemma).

${ }^{238}$ To illustrate with a stylized numerical example, suppose that all consumers used credit cards in equal amounts. Using cards gives each consumer $\$ 1.50$ in transactional benefits from a $\$ 100$ purchase, relative to cash or checks. Suppose further that the credit cards charge merchants $\$ 3$ and offer user rewards of $\$ 1$. Assuming that merchants fully pass on the fees as higher merchandise prices, cardholders will pay $\$ 3$ more in total in increased merchandise prices while reaping rewards of only $\$ 1$. Assuming for simplicity that the additional costs of operating the rewards program are zero, the card networks face $\$ 1$ in reward costs with the rest spent on advertising or retained as profits. In this situation, the net consumer welfare impact on the $\$ 100$ purchase is a harm of $\$ 0.50$ (i.e., $\$ 3$ price increase, offset by $\$ 1$ in rewards and $\$ 1.50$ in transactional benefit). Yet the Prisoner's Dilemma dynamics give every consumer the individual incentive to use the cards to get the $\$ 2.50$ benefit, rather than face the same increased merchandise prices without the shelter of rewards or transactional benefits. At the same time, the consumers would be better off if instead the cards charged merchants $\$ 1$, and were not permitted to offer rewards, in which case net consumer welfare would be positive $\$ 0.50$ (i.e., $\$ 1.50$ minus $\$ 1$ ). Note that in practice these effects would be mitigated at least to some extent by the Durbin Amendment's protection of the right to offer discounts for cash payment. See generally Tamás Briglevics \& Oz Shy, Why Don't Most Merchants Use Price Discounts to Steer Consumer Payment Choice?, Federal Reserve Bank of Boston Public Pol'y Discussion Paper 12-9 (2012).
} 
consumers - are harmed. ${ }^{239}$ Note that those consumers who do not use credit cards are not considered direct participants in the relevant market for credit card services to cardholders. However, their harm-which is essentially a passed-on overcharge plus a deadweight loss from the higher prices - is included in and derivative of the harm to merchants, who are participants in the relevant market for card acceptance services to merchants. Merchants themselves face further harm because even if merchants can fully pass on merchant fees as higher merchandise prices, they will sell less merchandise at those higher prices.

This Prisoner's Dilemma underpins another important error made by the Supreme Court, which future courts should be careful to avoid. The District Court had found that increased prices - specifically higher merchant fees and higher merchandise prices for most consumers (even taking into account cardholder rewards) — was evidence of anticompetitive harm. The Supreme Court rejected this evidence as insufficient and focused instead on output, explaining that volume of credit card transactions increased. But the Court failed to spot the fallacy here. The Prisoner's Dilemma creates incentives that tend to increase the number and dollar value of credit card transactions above the efficient competitive level at the expense of other forms of payment. ${ }^{240}$ The higher prices increased the dollar value of transactions. Thus, looking only at the dollar value of credit card transactions in isolation, calling it "output," and denying competitive concerns because that measure is increasing, amounts to another error. ${ }^{241}$ This point can be discerned in the states' briefing, ${ }^{242}$ though it appeared completely lost on the Court.

\footnotetext{
${ }^{239}$ See 88 F. Supp. 3d at 217 (citing Adam J. Levitin, Priceless? The Economic Costs of Credit Card Merchant Restraints, 55 UCLA L. REV. 1321, 1356 (2008) (noting regressivity of cross-subsidy)).

${ }^{240}$ This basic dynamic is familiar from other situations in which the costs of a practice are externalized to others: overproduction of pollution is a classic example. See, e.g., Richard L. Revesz, Rehabilitating Interstate Competition: Rethinking the "Race-To-The-Bottom" Rationale for Federal Environmental Regulation, 67 N.Y.U. L. REV. 1210, 1212 (1992).

${ }^{241}$ This is in addition to the Court's other separate (and familiar) error of assuming that, if output is rising or price is falling, competitive concerns are improbable. The fallacy here lies in the use of the wrong counterfactual: if output would have been rising faster, or by a greater amount, but-for the challenged conduct, then in the relevant sense there is an output reduction, even if output is increasing in an absolute sense. See, e.g.,138 S. Ct. at 2289 (dismissing the tendency of the restrictions to stifle competition because, among other things, "while these agreements have been in place, the credit-card market experienced expanding output and improved quality.").

${ }^{242}$ Brief for Petitioners at 47, Ohio v. Am. Express Co, 138 S. Ct. 2274 (No. 16-1454); see also, e.g., John Newman, The Output-Welfare Fallacy: A Modern Antitrust Paradox, 107 Iowa L. Rev. 563 (2022).
} 


\section{B. Cognizable Procompetitive Justifications: Distinguishing Efficiency Benefits from Extracted Rents}

The Amex Court appears to have misinterpreted some harms as procompetitive benefits by assuming that the provision of any cardholder reward was, by definition, a procompetitive benefit. ${ }^{243}$ But at least some of the cardholder benefits might be more accurately thought of as rent extraction orchestrated by American Express, in a manner analogous to buyer coordination, and externalized onto other consumers. This same issue also can arise in other platform antitrust cases.

To illustrate, consider a hypothetical in which a group of wealthy consumers band together and offer merchants the following terms: "Because we collectively represent a significant chunk of your most valuable consumer traffic, we jointly threaten not to shop at your stores unless you accept our use of payment cards that pay us large "transaction fees,' which you can fund by a general increase in your merchandise prices you charge to other consumers." 244

In this somewhat extreme hypothetical, the wealthy consumer group is functioning as a buyer group, but without any of the procompetitive benefits that may result from and can sometimes justify coordinated or joint purchasing. The group has engaged in no procompetitive economic integration and has not created any economies of scale in purchasing. ${ }^{245}$ In economic terms, this hypothetical group is a type of buyer cartel. In effect, the merchants' costs (and the prices paid by other consumers) have been driven up by the imposition of a cartel overcharge, and the wealthy participants pocket the surplus. Under most plausible conditions, the welfare of the merchants and all the other consumers will decline as a result. And if this buyer cartel is organized by an agent that extracts some of the fees for itself as margin, then the proportion of the cartel rent that reaches the wealthy consumers in the group will decline somewhat, increasing overall consumer harm even further.

This hypothetical illustrates how cardholder "rewards" extracted from merchants by jointly acting consumers and funded by a general increase in merchandise pricing may, at least to some extent, be seen to represent anticompetitive rent extraction through collective action rather than the

\footnotetext{
243 See, e.g., 138 S. Ct. at 2289-90 (treating investment in rewards as unambiguously procompetitive). ${ }^{244}$ Cf. 138 S. Ct. at 2288 ("[American Express] delivers wealthier cardholders who spend more money").

${ }^{245}$ See, e.g., Peter C. Carstensen, Buyer Cartels Versus Buying Groups: Legal Distinctions, Competitive Realities, and Antitrust Policy, 1 WM. \& MARY Bus. L. REV. 1 (Feb. 2010).
} 
fruits of procompetitive efficiencies. Indeed, in the hypothetical, there are no procompetitive efficiencies at all. The practice does not reduce transaction costs, and no joint-purchasing efficiency benefits are generated. The "rewards" for the participants are the rent extraction fruits of pure buyer collusion.

The Court's procompetitive explanation was that American Express's increased merchant fees "reflect increases in the value of its services and the cost of its transactions, not an ability to charge above a competitive price." ${ }^{246}$ But, in light of the hypothetical, a better characterization for at least some of the increment may be that the "value of its services" includes the fruits of higher fees - above the competitive level - extracted from merchants. On this view, "welcome acceptance" could be considered a euphemism for the desired rent-extraction mechanism. ${ }^{247}$ The record in Amex showed that American Express cardholders were among the merchants' most valuable consumers, which increased the risk to a merchant of these consumers turning elsewhere if the merchant chose not to accept American Express. ${ }^{248}$ Economically, each merchant could be understood as facing a potential boycott by a group of its highest-value customers.

We are not suggesting that American Express or other credit card networks are naked buyer cartels. Credit cards make paying for goods and services much easier, provide important payment services to merchants, and offer valuable revolving credit to cardholders. Nor are we suggesting that all cardholder benefits are invariably or even predominantly improper. Rather, cardholder rewards should not be assumed to be, dollar for dollar, evidence of a procompetitive benefit. They may represent a combination of both procompetitive benefits and mere extracted rents. ${ }^{249} \mathrm{~A}$ full and fair assessment of the effects in Amex would have taken this dynamic seriously, aimed to measure its significance, and reflected it in measuring the nature

\footnotetext{
${ }^{246} I d$.

${ }^{247}$ Herbert Hovenkamp makes a similar point. Herbert Hovenkamp, Platforms and the Rule of Reason: The American Express Case, 2019 Columbia Bus. L. REv. 35, 66-67 (2019) ('Welcome acceptance' in this case apparently meant that the buyer should be prevented from being offered or even told about the availability of a cheaper alternative.").

248138 S. Ct. at 2281.

${ }^{249}$ Compare, e.g., John M. Newman, Antitrust in Zero-Price Markets: Applications, 94 Wash. U. L. Rev. 49, 80-81 (2016) (pointing out that "[i]t is an ancient tenet of the law that disposing of ill-gotten gains in an admirable manner is no defense," and concluding that "Robin Hood has no place in antitrust doctrine").
} 
and magnitude of any procompetitive benefits. Future courts should avoid repeating this error. ${ }^{250}$

\section{Conducting the Balancing}

In Amex, there was ample evidence that the antisteering rules, along with Visa and MasterCard's parallel restraints, drove up merchant fees, inflated merchandise prices for cardholding and non-cardholding consumers, and fueled a destructive Prisoner's Dilemma that harmed most merchants and their customers. At the same time, the evidence of substantial, genuinely procompetitive benefits sufficient to exceed the harms was weak, particularly since American Express and the other card networks extracted some of the higher merchant fees. ${ }^{251}$ Given the weakness of American Express's evidence of cardholder benefits, we doubt that it would have been necessary to conduct a weighing in Amex itself. But, in the interests of clarifying a framework for future cases, we outline that analysis here.

The District Court concluded that most of American Express's proposed procompetitive benefits were either theoretically flawed or not backed up by evidence. However, to illustrate the proposed analysis, we consider one of the arguments that at least has the virtue of being legally cognizable: the claim that American Express had made investments in its brand that exerted a "halo" or "credentialing" effect on merchants that accepted the card and drove consumer traffic to them. ${ }^{252}$

Suppose that American Express had produced evidence that merchants derived a benefit of increased customer traffic and purchases by merely advertising acceptance of the card, and that this served as a signal of prestige. Suppose that it also produced evidence that these benefits were caused by American Express's investments in advertising, quality of service, and in screening for reputable merchants. Assume further that there were reasonable grounds to believe that merchants would have the incentive to free ride on Amex's efforts by violating its "welcome acceptance" policy and redirecting the customers who were influenced by this signal to use

\footnotetext{
250 Similar dynamics could present themselves in the context of MFN-plus agreements, in which a purchaser secures a "discount" against the terms offered by a counterparty to others, funded by a general increase in the prices charged by the counterparty. See, e.g., Complaint, United States v. Blue Cross Blue Shield of Michigan, No. 2:10-cv-15155-DPH-MKM (E.D. Mich. Oct. 18, 2010); $c f$. Kartell v. Blue Shield of Mass., Inc., 749 F.2d 922 (1st Cir. 1984); North Jackson Pharmacy, Inc. v. Caremark RX, Inc., 385 F. Supp. 2d 740 (N.D. Ill. 2005).

${ }^{251}$ If some of the rewards are treated as mere fruits of buyer collusion, the differential between harms and cognizable benefits would be even larger.

${ }^{252}$ See supra Section I.B.
} 
another, lower cost payment method. Finally, assume that American Express could show that the antisteering rules eliminated this opportunity for merchant free riding and thereby encouraged it to further invest in this credentialing effect.

If American Express could show all this, the balancing step would require finding that the anticompetitive harms proven by the plaintiff as a result of the higher fees were fully offset by the incremental beneficial effects on investment under the antisteering rules, compared to the investment that would take place without such rules. While the language of magnitudes and offsets suggests the tidiness of a simple equation, this determination would depend on the balancing standard applied by the court.

The Court treated the relevant harms, for the purposes of balancing, as including only the increased fees paid by merchants. ${ }^{253}$ But this misses at least two sets of harms which ought to have been included, consistent with the symmetry principle described in Part II: (1) deadweight losses that result from unsatisfied customer demand in response to higher merchandise prices $^{254}$; and (2) the incremental effects of American Express's antisteering rules on the merchant fees charged by other card networks. ${ }^{255}$ It also ignores the innovation harms identified by the District Court. ${ }^{256}$

On a full accounting, it is likely that American Express would have failed to carry its burden under most of the alternative standards set out in Part II. It obviously would fail under the "no consumer harmed" standard and the nogroup harmed standard, because of the clear harms to the individuals who do not pay with credit cards, to those who do not pay with American Express credit cards, or to those who do not qualify for rewards. American Express would fail under the "no side harmed" standard because the increase in the merchant fees lead to higher merchandise prices that directly harm purchasers and the merchants. It also would surely fail under the "harm-weighted" standard, given the weakness of benefit evidence.

It is theoretically possible that American Express could have prevailed under a "benefit-weighted" standard that favored defendants. But even that seems highly unlikely given the record. ${ }^{257}$ The District Court rejected the

\footnotetext{
${ }^{253}$ See 138 S. Ct. at $2287-88$.

254 Cardholders whose rewards do not outweigh higher merchandise prices bear some of these deadweight losses.

255 See 88 F. Supp. 3d at 202.

${ }^{256}$ United States v. American Exp. Co., 88 F. Supp. 3d 143, 217-18 (E.D.N.Y. 2015).

${ }^{257}$ As Hovenkamp notes, the Court did not disturb the District Court's findings of fact: "[r]ather, it simply ignored them." Herbert Hovenkamp, Platforms and the Rule of Reason: The American Express Case, 2019 Columbia Bus. L. Rev. 35, 89 (2019).
} 
proffered evidence of procompetitive benefits at trial and found that the Amex trailed its competitors in any "credentialling effect." If the cardholder rewards were cognizable as a procompetitive benefit (despite the Prisoners' Dilemma discussed above), the balance still may not have come out in Amex's favor. The DOJ's economic expert and the District Court concluded that American Express passed on only a portion of the higher merchant fees as rewards. ${ }^{258}$ And, finally, even if American Express had made its own cardholders whole with rewards, and even if Visa and MasterCard issuers did the same, there would still be larger harms on the merchant side (including those passed on harms to the purchasers that did not use credit cards). ${ }^{259}$ Significant pro-defendant weighting or huge other efficiencies (such as a huge credentialing effect of a kind nowhere in the record) would likely be needed to offset this effect. The rules would be even less likely to survive the application of a harm-weighted standard.

As a result, under the kind of balancing framework that we commend to future courts, the rules would not plausibly have passed muster.

\section{MOVING ON FROM AMEX}

In the preceding pages, we have described and applied our proposed framework for the antitrust analysis of platform cases, taking Amex as our foil but aiming for a sounder approach that can guide adjudication in future cases. No doubt the framework will strike many as less than revolutionary. We hope so. A key benefit of our approach is that it preserves as much of the fabric of existing law as possible. The basic burden-shifting approach under the rule of reason is readily adaptable to platforms with the principled relaxation of the rule against multi-market balancing we propose.

The problem, of course, is what can be done about Amex itself. We suggest three different options, offered to the three different entities who have the power to act: the Supreme Court, lower courts, and Congress.

\section{A. A Direct Fix for the Supreme Court: Overrule Amex}

The ideal path would be for the Supreme Court to overrule Amex directly and expressly embrace the analytical framework we propose for all cases,

\footnotetext{
25888 F. Supp. 3d at 199.

${ }^{259}$ In the extreme, suppose that all the networks raised their merchant fees by the same amount, all purchases were made with credit cards, and all the merchants fully passed-on the higher fees as higher merchandise prices. In this case, if all consumers reckoned the higher rewards into their purchase decisions, then there would be no net harms or benefits. The higher merchants' fees would be completely neutralized. Of course, these extreme conditions are purely theoretical and would not be expected in practice.
} 
including future transaction platform cases. This would involve correcting its approach to market definition and repudiating the idea that a plaintiff must disprove the possibility of offsetting benefits in a transaction platform case. The Court should also eliminate the requirement of proving market power by formally defining a market and gauging market share in vertical restraint cases when there is direct evidence of market power or anticompetitive effects.

In place of the approach taken by the Amex majority, the Court could adopt instead the framework we describe in Part II. This approach preserves the possibility of cross-platform balancing in appropriate platform cases while still permitting direct evidence of market power and following the substitutability principle when defining markets. To do so, the Court would implement a narrow platform exception, allowing multi-market balancing across multiple sides of a platform under the three limiting conditions described above: (1) causal connection as the test for counting beneficial effects on other sides of the platform; (2) correct allocation of the burdens of proof (harms for plaintiffs, benefits for defendants); and (3) the symmetry principle that harms and benefits on all sides of the platform must be included to protect against cherry-picking that may give a court a misleading picture of the balance of a measure's effects.

The Court has often made substantial course corrections in its 130-year exposition of the Sherman Act. Perhaps the most famous was the overarching Section 1 rule of reason standard itself, created when Standard Oil implicitly overruled Trans-Missouri Freight. ${ }^{260}$ Other dramatic reversals have included the multiple revisions of the law of non-price intrabrand vertical restraints, ${ }^{261}$ the law of minimum resale price maintenance, ${ }^{262}$ the law of maximum resale price maintenance, ${ }^{263}$ the market-power presumption in patent cases, ${ }^{264}$ the predatory pricing standard, ${ }^{265}$ and even the constitutional reach of the Sherman Act itself. ${ }^{266}$ More generally, in both

\footnotetext{
${ }^{260}$ Standard Oil Co. v. U.S., 221 U.S. 1 (1911) (tacitly overruling U.S. v. Joint-Traffic Ass'n, 171 U.S. 505 (1898) and United States v. Trans-Missouri Freight Ass'n, 166 U.S. 290 (1897)).

${ }^{261}$ GTE Sylvania Inc., 433 U.S. 36 (overruling United States v. Arnold, Schwinn \& Co., 388 U.S. 365 (1967).

262 Leegin, 551 U.S. 877 (overruling Dr. Miles Medical Co. v. John D. Park \& Sons Co., 220 U.S. 373 (1911) and holding minimum resale price maintenance to be subject to rule-of-reason analysis)

263 State Oil Co. v. Khan, 522 U.S. 3 (1997) (overruling Albrecht v. Herald Co., 390 U.S. 145 (1968) and holding minimum resale price maintenance to be subject to rule-of-reason analysis).

${ }^{264}$ Illinois Tool Works, Inc. v. Independent Ink, Inc., 547 U.S. 28 (2006) (overruling Jefferson Parish, 466 U.S. 2).

${ }^{265}$ Brooke Group Ltd. v. Brown \& Williamson Tobacco Corp., 509 U.S. 209 (1993) (overruling Utah Pie Co. v. Continental Baking Co., 386 U.S. 685 (1967)).

266 Swift \& Co. v. United States, 196 U.S. 375 (1905) (implicitly overruling United States v. E. C. Knight Co., 156 U.S. 1 (1895)).
} 
antitrust and non-antitrust cases, the Court has shown a pragmatic willingness to correct what it views as errors when they are important enough, when they are sufficiently clear, and when the threat of harm is obvious. $^{267}$

Those factors are amply satisfied here. Amex has already led directly to a dead wrong decision in Sabre/Farelogix that would have led to immediate consumer harm had the UK antitrust authority not intervened. ${ }^{268}$ The courts are drowning in arguments - from the arguable to the meritless - by defendants hoping to avail themselves of the "Amex exceptions" to various established points of antitrust orthodoxy from market definition to proof burdens. ${ }^{269}$ A chorus of critical commentary should help the Court see that this decision is not worth defending. ${ }^{270}$ In the years since Amex was decided, a panoply of antitrust litigation has been initiated against the socalled "Big Tech" platforms. ${ }^{271}$ These cases deserve pragmatic, careful analysis. To the extent that Amex impedes such analysis, it is unjustified and should be overruled.

\section{B. A Cry for Congressional Help: Statutory Intervention}

The second hope for a direct fix lies with the legislature. Although Congress has historically been reluctant to micromanage antitrust doctrine (a policy that we think generally wise), legislative willingness to revisit and modify the antitrust laws seems to be at a generational peak. In that light, fixing Amex should be near the top of Congress's antitrust agenda. ${ }^{272}$ While we do

${ }^{267}$ When deciding whether to relax the general principle of stare decisis, the Court considers several factors, with the goal of "gaug[ing] the respective costs of reaffirming and overruling a prior case." Planned Parenthood of Southeastern Pa. v. Casey, 505 U.S. 833, 854 (1992). These factors include: (1) whether the rule has proven to be intolerable simply in defying practical workability, (2) whether the rule is subject to a kind of reliance that would lend a special hardship to the consequences of overruling and add inequity to the cost of repudiation, (3) whether related principles of law have so far developed as to have left the old rule no more than a remnant of abandoned doctrine, or (4) whether facts have so changed, or come to be seen so differently, as to have robbed the old rule of significant application or justification. Id.

${ }^{268}$ See 452 F. Supp. 3d at 136.

269 See supra notes $163-65$.

${ }^{270}$ See supra note $3 .{ }^{271}$ See, e.g., Complaint, United States v. Google LLC, No. 1:20-cv-03010-APM (D.D.C. Oct. 20, 2020); Substitute Amended Complaint, FTC v. Facebook, No.: 1:20-cv-03590-JEB (D.D.C. Sept. 8, 2021).

271 See, e.g., Complaint, United States v. Google LLC, No. 1:20-cv-03010-APM (D.D.C. Oct. 20, 2020); Substitute Amended Complaint, FTC v. Facebook, No.: 1:20-cv-03590-JEB (D.D.C. Sept. 8, 2021).

${ }^{272}$ We note that recommendations to "fix Amex" have featured prominently in recent proposals. See, e.g., Competition and Antitrust Law Enforcement Act ("CALERA"), S. 225, 117th Cong. (2021); Subcomm. on Antitrust, Com. And Admin. L. of the H. COMM. On the Judiciary, 116Th Cong., InVESTIGATION OF COMPETITION IN Digital MARKeTS: MAJORITY STAFF REPORT AND 
not suggest that Congress should intervene to correct every bad precedent, correction could be achieved here simply and by reaffirming wellrecognized antitrust principles.

The best solution turns on the fact - emphasized throughout Part II - that the Court grounded its analysis in market definition. The single "two-sided" transaction platform market definition allowed the Court to avoid the express question of multi-market balancing and to characterize the record as telling an incomplete story of harm to a transacting pair. Correcting the market definition holding would: (1) restore the integrity of the market definition substitution principle; (2) force future courts to explicitly tackle the multi-market balancing question; and (3) ensure that future courts would not be tempted to reconceive the possibility of out-of-market benefits as a deficiency in a plaintiff's showing of in-market harms.

To that end, we recommend that the Sherman Act be amended to read, in relevant part:

In a case brought under the antitrust laws, any definition of a relevant antitrust market shall be conducted by reference to the principle of substitutability.

This provision shall not be construed to require the formal definition of a relevant antitrust market in cases where such definition would not otherwise be required, including cases where competitive harm is shown by direct evidence.

This surgical legislative intervention would go further than CALERA by protecting against the errors of Amex in merger cases as well as conduct cases. ${ }^{273}$ Note also that we do not recommend specifying any particular manifestation of the substitutability principle - nor even confining it to demand-side substitution - as doing so would go beyond simply fixing Amex and could needlessly interfere with the development of market definition doctrine.

RECOMMENDATIONS 399 (Oct. 2020) (proposing “[o]verriding Ohio v. American Express by clarifying that cases involving platforms do not require plaintiffs to establish harm to both sets of customers").

${ }^{273}$ Section 13 of the proposed legislation, which eliminates any strict market definition requirement and reaffirms the direct-evidence standard, largely re-states existing law, although it corrects the bizarre limitation introduced in Amex's footnote 7. See supra note 102 and accompanying text. But Section $26 \mathrm{~A}$ of the proposed legislation, which underscores that exclusionary conduct may violate the law even if it does not harm competition on more than one side of a multisided platform, does not seem to correct the Amex Court's errors on either market definition or burdens of proof. 


\section{A Stopgap Measure for Lower Courts: Keeping AmEx Within Bounds}

Even if the Court or Congress chooses to overrule the unworkable dimensions of Amex, that process may take time. In the meantime, the best path for lower courts is to take the Amex opinion at its word and narrowly construe its holdings. Both the market definition and effects analyses can and should be understood as narrow, fact-bound conclusions.

Amex is limited on its face to transaction platforms that meet the following conditions: (1) activity on both sides is strictly joint and simultaneous, (2) relevant services are limited to the execution of transactions, and (3) such platforms compete only with other multisided platforms. ${ }^{274}$ Those limitations should be taken seriously, as the Court directed, despite our concerns about the economics of the categorization. ${ }^{275}$ "Mixed" platformsoffering transactional services as well as nontransactional services, such as market-making services - should be subject to Amex only with respect to the restraints on the provision of transactional services.

Many platforms provide both transactional and nontransactional services. For example, ecommerce platforms and app stores commonly provide nontransactional services (like search, curation, and information services) to users and transactional services (like app purchases) to user-merchant or user-developer pairs. Likewise, a ridesharing platform provides nontransactional services (like search) to users and drivers separately, and then transactional services (like ride monitoring and payment processing) jointly and simultaneously to the user-driver pair after they have chosen to trade. Amex should apply to such mixed platforms only to the extent that they offer transactional services and the antitrust theory of harm pertains to such services. ${ }^{276}$

There is some room for optimism. United States $v$. Charlotte-Mecklenburg Hospital Authority demonstrates a district court's ability to limit Amex to its facts and properly apply the rule of reason in the face of a defendant's claims to special treatment by reason of platform status. In June 2016, the

\footnotetext{
274138 S. Ct. at 2278.

275 See supra Section II.A.3.

${ }^{276}$ Newspapers, as the Court correctly noted, see 138 S. Ct. at 2286, are not transaction platforms at all in the relevant sense. Advertisers and readers consume the services of a newspaper separately and independently. After a reader and an advertiser choose to transact, they do not purchase services from the newspaper at all. Oddly, the Court claimed that newspapers exhibit only one-directional indirect network effects: this is doubtful at best. See, e.g., Benjamin Klein et al., Competition in Two-Sided Markets: The Antitrust Economics of Payment Card Interchange Fees, 73 Antitrust L. J. 571, 577-79 (2006) (using newspaper economics to illustrate two-sided dynamics, including bidirectional indirect network effects).
} 
DOJ filed a complaint against Carolinas HealthCare System ("CHS") challenging anti-steering provisions in CHS's contracts with commercial health insurers. ${ }^{277}$ Following the Second Circuit's Amex decision in September 2016, CHS argued that its provisions mirrored those at issue in the Amex case and that the Second Circuit's analysis should guide the analysis in this case. ${ }^{278}$ In a 2017 order, the Western District of North Carolina rejected the argument, emphasizing the need for a traditional market-specific analysis. ${ }^{279}$ The District Court explained that it was not bound by the Second Circuit and concluded that the Second Circuit's reasoning should be limited to credit card markets. ${ }^{280}$ The parties settled before Amex was decided by the Supreme Court, but the District Court's focus on the particular history and context of the market at issue would be equally appropriate today. ${ }^{281}$

\section{CONCLUSION}

The last four years have taught us that the errors of Amex are every bit as serious and harmful as commentators feared when it first came down. ${ }^{282}$ In the preceding pages, we outline a better approach: a path that restores principle and vigor to platform antitrust while respecting the special nature of certain platform businesses. We argue that the substitutability approach to market definition should be restored in platform cases, and that traditional allocations of burdens of proof must be preserved. And we suggest a limited and principled rule for the cross-platform balancing of harms and benefits.

We hope that the Supreme Court will swiftly correct its error at the first opportunity. However, if it fails to do so, neither the lower courts nor Congress are powerless. Lower courts can and should heed the many limiting principles on the face of the Court's own decision. And Congress could undertake a scalpel-like intervention with confidence. Correct the market-definition component, and the rest will likely work itself out.

\footnotetext{
${ }^{277}$ Complaint, United States v. Charlotte-Mecklenburg Hosp. Auth., No. 3:16-cv-00311-RJC-DCK (W.D.N.C. June 9, 2016), ECF No. 1.

${ }^{278}$ Supplemental Briefing of Defendant on United States v. Am. Express, United States v. CharlotteMecklenburg Hosp. Auth., No. 3:16-cv-00311-RJC-DCK (W.D.N.C. Oct. 12, 2016).

279 Order, United States v. Charlotte-Mecklenburg Hosp. Auth., No. 3:16-cv-00311-RJC-DCK (W.D.N.C. Mar. 30, 2017), ECF No. 46.

${ }^{280} \mathrm{Id}$. at 16.

${ }^{281}$ Final Judgment, United States v. Charlotte-Mecklenburg Hosp. Auth., No. 3:16-cv-00311-RJCDCK (W.D.N.C. Apr. 24, 2019), ECF No. 99.

${ }^{282}$ See supra note 3.
} 
Antitrust has recovered from grievous mistakes before; we trust it will do so again. 